\title{
The impact of classroom, school, neighborhood, and institutional factors on teachers' expectations
}

Citation for published version (APA):

Becker, D., \& Wessling, K. (2020). The impact of classroom, school, neighborhood, and institutional factors on teachers' expectations. ROA. ROA Research Memoranda No. 004 https://doi.org/10.26481/umaror.2020004

Document status and date:

Published: 14/04/2020

DOI:

10.26481/umaror.2020004

Document Version:

Publisher's PDF, also known as Version of record

\section{Please check the document version of this publication:}

- A submitted manuscript is the version of the article upon submission and before peer-review. There can be important differences between the submitted version and the official published version of record.

People interested in the research are advised to contact the author for the final version of the publication, or visit the DOI to the publisher's website.

- The final author version and the galley proof are versions of the publication after peer review.

- The final published version features the final layout of the paper including the volume, issue and page numbers.

Link to publication

\footnotetext{
General rights rights.

- You may freely distribute the URL identifying the publication in the public portal. please follow below link for the End User Agreement:

www.umlib.nl/taverne-license

Take down policy

If you believe that this document breaches copyright please contact us at:

repository@maastrichtuniversity.nl

providing details and we will investigate your claim.
}

Copyright and moral rights for the publications made accessible in the public portal are retained by the authors and/or other copyright owners and it is a condition of accessing publications that users recognise and abide by the legal requirements associated with these

- Users may download and print one copy of any publication from the public portal for the purpose of private study or research.

- You may not further distribute the material or use it for any profit-making activity or commercial gain

If the publication is distributed under the terms of Article $25 \mathrm{fa}$ of the Dutch Copyright Act, indicated by the "Taverne" license above, 


\section{Maastricht University ROA}

The impact of classroom, school, neighborhood, and institutional factors on teachers' expectations

Dominik Becker Katarina Weßling

\section{ROA Research Memorandum}

ROA-RM-2020/4

Researchcentrum voor Onderwijs en Arbeidsmarkt | ROA Research Centre for Education and the Labour Market / ROA 


\title{
The impact of classroom, school, neighborhood, and institutional factors on teachers' expectations
}

\author{
Dominik Becker \\ Katarina Weßling
}

ROA-RM-2020/4

April 2020

Research Centre for Education and the Labour Market Maastricht University

P.O. Box 616, 6200 MD Maastricht, The Netherlands

$\mathrm{T}+31433883647 \mathrm{~F}+31433884914$

secretary-roa-sbe@maastrichtuniversity.nl

www.roa.nl 


\section{Abstract \\ The impact of classroom, school, neighborhood, and institutional factors on teachers' expectations *}

Teachers represent a crucial dimension of social stratification in the school system. Their assessments of students matter by exerting short-term effects on students' motivation and achievement, but also by influencing students' educational prospects. Research shows that teachers' assessments are reasonably accurate. However, there is a residual component of inaccuracy emerging from individual-level factors (e.g., students' social or immigrant origin) as well as from classroom and school composition. In the present contribution, we add to this literature by providing a dual-process explanation on how contextual conditions on several levels, i.e., classroom, school, neighborhood and institution simultaneously frame teachers' expectations of their students. We test our theoretical model by using data comprising information on teachers, students, parents, and contextual settings of German elementary schools. We exploit institutional variations that influence the extent to which teachers perceive their expectations as relevant (i.e., binding versus non-binding recommendations for secondary school tracks). Results show that teachers' expectations are positively framed by a high share of students with immigrant background in the classroom. Yet, this effect is only valid for native students. Furthermore, we observe mutually reinforcing framing effects of the classroom's and the neighborhood's social composition on teachers' expectations. Finally, context influences are attenuated when teachers perceive their expectations as more relevant (i.e. track recommendations are binding).

JEL classification: C33, I24, D81

Keywords: teachers' expectations, dual-process model, classroom composition, neighborhood effects, stratified education systems

\section{Dominik Becker}

Federal Institute for Vocational Education

and Training (BIBB),

Division 1.3 - Economics of VET

P.O. Box 201264

D-53142 Bonn

Germany

dominik.becker@bibb.de

\author{
Katarina Weßling \\ Maastricht University \\ ROA \\ P.O. Box 616 \\ NL-6200 MD Maastricht \\ The Netherlands \\ k.wessling@maastrichtuniversity.nl
}

\footnotetext{
We would like to thank the LEAD Research Network, University of Tübingen and the Bamberg Graduate School of Social Sciences (BAGSS) for financing our research stays at the Leibniz Institute for Educational Trajectories (LIfBi) to carry out the analyses for this paper.

Earlier versions of this paper have been presented at the Tübingen Workshop on Educational Policies, Processes and Social Inequalities, the LIfBi colloquium, the Learning \& Work Seminar at Maastricht University, the Educational Inequality Conference at the Amsterdam Centre for Inequality Studies (AMCIS), the World Congress of the International Sociological Association (ISA), Toronto, as well as the Social Sciences Research Seminar at the University of Konstanz. We thank all participants for their helpful comments; in particular Steffen Hillmert, Corinna Kleinert, Benjamin Nagengast, Pia Schober, Ulrich Trautwein, and Herman van de Werfhorst provided valuable input to improve the paper. We would like to thank Stan Vermeulen and Mark Levels for carefully reviewing our paper.

Funding: This paper originated within the project "Flexibility of Educational Systems and Social Inequality in Educational Outcomes" and is funded by the Nationaal Regieorgaan Onderwijsonderzoek (NRO).
} 


\section{Introduction}

Teachers represent a crucial dimension of social stratification in the school system. They matter by exerting short-term effects on students' motivational development (Dietrich, Dicke, Kracke et al. 2015) and achievement (Jussim and Harber 2005, Rosenthal and Jacobson 1968), but also in a longer run by shaping students' life chances in terms of educational transition propensities (Becker 2013) or labormarket income (Chetty, Friedman and Rockoff 2014, Chetty, Friedman, Rockoff et al. 2014).

The present study analyzes the influence of multiple contextual conditions on teachers' expectations. Expectations of teachers about their students represent one specific form of assessments. Another form of assessments are judgements which are less forecasting than assessments. Teachers' assessments may either constitute accurate evaluations or forecasts of students' latent aptitude or traits, or comprise a component of inaccuracy (Biggs 2009). Empirically, it has been observed that teacher assessments are reasonably accurate (Feron, Schils and Ter Weel 2016, Südkamp, Kaiser and Möller 2012). Yet, there is a residual component of inaccuracy emerging from both student-level factors such as social or ethnic background (Farkas 2003, Rist 1970) and contextual-level factors such as the social and academic composition schools and classrooms (Boone, Thys, Van Avermaet et al. 2018, Ready and Wright 2011). The present study contributes to the literature by analyzing the simultaneous influence of multiple contextual conditions, i.e., the classroom, the school, the neighborbood, and the institutional setting on teachers' expectations of their students in three consecutive years of elementary school in Germany.

A large body of literature shows that contexts beyond the school or classroom, such as characteristics of the neighborhood (e.g., neighborhoods' social or immigrant composition) or institutional factors (e.g., stratification or standardization of educational systems), are highly consequential for a variety of educational outcomes such as student achievement (Ainsworth 2002, Carlson and Cowen 2015, van de Werfhorst 2014), aspirations (Alwin and Otto 1977, Buchmann and Park 2009) or educational attainment (Alexander and Eckland 1975, Owens 2010, Van de Werfhorst and Mijs 2010). This line of research is surprisingly unrelated to research on teachers' assessments. However, contexts beyond the school or classroom could be relevant for teachers' assessment for the following reasons: Various studies show the impact of teachers' social and ethnic stereotypes on teachers' assessments (Farkas 2003, McGrady and Reynolds 2013). At the same time, prior research has already argued that stereotypes can expand towards the level of neighborhoods (Ellen 2000). Moreover, there is ample evidence that neighborhood composition may be related to inhabitants' discrimination in several domains (for an extensive review see Pager and Shepherd 2008). Concerning teachers, research shows that they can also be framed by situational cues of the neighborhood (e.g., 'black, 'dangerous' or 'poor') when evaluating students (Morris 
Following this, we contribute to the literature by assessing the separate and combined influences of several potentially relevant contexts on teachers' expectations of elementary school students in Germany. In doing so, we provide an extensive literature review on research discussing the relevance of contexts for teacher assessments. We introduce a theoretical model that allows to formulate hypotheses on the simultaneous influence of contexts.

A general argument to integrate these various contexts follows social ecological and neighbourhood theory which suggest that individuals are not located in single social contexts but are acting in several contexts simultaneously (Bronfenbrenner 1977, Park, Burgess and McKenzie 1925, p. 25). For other educational outcomes, research has started to analyze how educational contexts such as schools and neighborhoods exert mutually reinforcing (i.e., multiplicative) effects on students' achievement or their educational transitions (Owens 2010, Weßling, Hartung and Hillmert 2015). So far, studies of teachers' assessments have both theoretically and empirically neglected the explanatory potential of simultaneous contextual settings.

Theoretically, we provide a dual-process explanation (Kroneberg and Kalter 2012, Lizardo, Mowry, Sepulvado et al. 2016, Miles, Charron-Chénier and Schleifer 2019, Vaisey 2009) of how educational contexts on different levels jointly affect elementary school teachers' expectations of their students. We test our hypotheses empirically by using data from the German National Educational Panel Study (NEPSSC2). Germany provides a valid case to study teachers' assessments in elementary school because the German education system is characterized by rigid and early tracking in which elementary school teachers' expectations of their students are highly relevant for students' educational placement in secondary school. Moreover, education in Germany is organized in a federal system, meaning there is institutional variation in the extent to which relevance is attributed to teachers' assessments in general (i.e. binding versus nonbinding recommendations for secondary school tracks at the end of elementary school). NEPS-SC2 provides an excellent data base allowing us to link information on teachers, students, and parents and provides the possibility to observe aggregated information of individuals on the level of classroom, school, neighborhood and institution. The dependent variable measures whether elementary school teachers expect their students to (1) attend and accomplish the academic secondary track versus (2) not attending and graduating from academic secondary school. Results show that a high share of students with immigrant background in the classroom increases teachers' expectations, however, this only holds for native students. Moreover, we observe mutually reinforcing framing effects of the social composition of classrooms and neighborhoods on teachers' expectations. Overall, these classroom and neighborhood effects are attenuated or even disappear when institutional preconditions attribute more relevance to the 
teachers' assessments (binding track recommendations).

\section{Literature review}

\section{Definition of teacher assessments}

For teachers' assessments of their students, a distinction can be made between teacher judgments in terms of assessments of students' current performance, and expectations in the sense of forecasts of students' future achievement or development (Meissel, Meyer, Yao et al. 2017). Students' grades are well-known judgments that are regularly communicated to the students. Similarly, in stratified educational systems, students (and parents) have knowledge about teachers' track recommendations before the transition to secondary school. In addition, many studies survey teachers' judgments or expectations, which are not reported to their students. In our empirical analyses we will focus on teachers' expectations, but in line with the conceptual contribution of our paper we provide a more extensive overview on the state of research.

A frequently debated issue in the corresponding literature concerns the question of accuracy of teachers' assessments. In that respect, two conceptual and a methodological challenge can be identified. First, no consistent criteria of accuracy have been defined yet (Südkamp et al. 2012). Second, whatever list of criteria of accuracy is set, there might always exist achievement-related information that is available to the teacher only but not to the researcher. Third, even observed indicators might map the construct of interest only with measurement error. Consequently, it has to be acknowledged that any empirical identification strategy of (in)accuracy of teachers' expectations is only conditional on the available indicators.

Nonetheless, it is mostly consensual that teachers' assessments can be called 'accurate' if they rely on established measures of students' performance and educational motivation, while they may be called 'inaccurate' if they systematically deviate from the former criteria, e.g., when relying on physical appearance, social status, or stereotypes (Hinnant, O'Brien and Ghazarian 2009, Jussim 1986, Madon, Jussim and Eccles 1997, Ready and Wright 2011, Südkamp et al. 2012). The empirical state of research indicates that to the largest part, teachers' assessments are accurate in the above sense (Feron et al. 2016, Südkamp et al. 2012).

\section{Individual-level influences}

Among potential sources of inaccurate assessment criteria, students' social and ethnic origin have been extensively discussed. In this respect, Bourdieu's notion of habitus (Bourdieu 1973, Bourdieu 1986) 
implies that teachers might hold lower assessments of lower-SES and ethnic minority or immigrant students because the latter show a larger cultural distance to accepted norms, values, linguistic codes and modes of behavior of the school system than middle-class or native students do (also see Bernstein 1971, Bernstein 1981). An additional source of inaccuracy might be social or racial stereotyping. According to the theoretical state of research in social psychology, stereotypes attribute (perceived) group characteristics to particular group members (Fiske 1993, Tajfel 1982). While stereotyping simplifies information processing for the categorizing individual, it is evidently prone to errors at the same time. Concretely, teachers might consider low-SES and ethnic minority or immigrant students to be less capable or motivated just because of their social group membership (Farkas 2003, Jussim, Eccles and Madon 1996, McGrady and Reynolds 2013).

Empirical research supports these arguments. Determinants such as students' social and ethnic or immigrant background are notable predictors of teachers' assessments - which are robust against multivariate controls for criteria of accuracy such as academic ability on the one hand (Baudson, Fischbach and Preckel 2016, Hinnant et al. 2009, Meissel et al. 2017, Tach and Farkas 2006, Tenenbaum and Ruck 2007), and experimental manipulation on the other hand (Glock and Krolak-Schwerdt 2013, but see Kaiser, Südkamp and Möller 2017 for contradicting evidence). Students' social and ethnic background affects teachers' assessments via social and ethnic stereotyping (Dunkake and Schuchart 2015, Dunne and Gazeley 2008, Farkas 2003). Moreover, once teachers have shaped concrete expectations of their students, expectancy effects on later student achievement have been observed to be stronger for low-SES and ethnic minority or immigrant students (Hinnant et al. 2009, Jussim et al. 1996, Madon et al. 1997, Rist 1970, Sorhagen 2013).

\section{Contextual-level influences}

\section{Schools and classrooms}

While the state of research on individual-level determinants of (in)accuracy of teachers' assessments is consistent, we observe both theoretical and empirical inconsistencies for contextual-level determinants. Theoretically, two frame-of-reference mechanisms are plausible (Boone et al. 2018, Davis 1966): On the one hand, a more beneficial social composition of schools or classrooms could lead to a Halo effect in that teachers hold higher expectations of students situated in contexts that teachers perceive to be more favorable. On the other hand, teachers could increase their academic standards as a consequence of a Grading-on-a-curve effect, resulting in lower expectations of students in educational contexts perceived as more favorable (McKown and Weinstein 2008, Ready and Wright 2011). Beyond that, there might be additional mechanisms influencing in particular students' track recommendations: If teachers anticipate future discrimination of low-SES or immigrant students, or just want to circumvent conflicts with high- 
SES and/or majority parents (Schulze, Wolter and Unger 2009), a higher share of low-SES or migrant students would be assigned to lower tracks.

Furthermore, conceptual arguments on stereotyping contribute towards explaining the influence of social and ethnic composition on teachers' assessments. On the one hand, both Blau's (1960) structural theory and Zajonc's (1968) mere exposure hypothesis predict that a higher share of minority-group members in a social context results in more positive attitudes of majority-group members about the minority because it is more likely to interact and create familiarity with the majority. On the other hand, Blalock's (1956) theory of group threat indicates that an increase in minority group size might threaten majority group members and stimulate negative attitudes. Thus, stereotyping theory could predict both positive (Blau 1960, Zajonc 1968) and negative effects of school or classroom-level share of low-SES or migrant students on teachers' assessments of their students.

All in all, theoretical approaches arrive at different conclusions about potential effects of contexts on teachers' assessments of students. Unfortunately, these theoretical inconsistencies cannot be resolved by the empirical state of research, since we find that the existing studies on the effects of school and classroom contexts remarkably differ in observing either positive effects, negative effects, or no effects at all (for an extensive overview of empirical studies on context effects on teachers' assessment, see table $1)$.

\section{Neighborhoods}

There are theoretical arguments suggesting that - in addition to classroom and school effects - the neighborhood surrounding the school might shape teachers' assessments. Collective socialization and contagion mechanisms assume that neighborhoods with a favorable social composition exert a positive impact on students' educational outcomes (Crane 1991, Jencks and Mayer 1990). In contrast, the relative deprivation hypothesis predicts just the opposite: students get more deprived in more favorable neighborhoods due to social comparison processes (e.g., Canache 1996), implying a negative effect on academic outcomes. Similarly, as mentioned above, mechanisms such as stigmatization or stereotypes can also play a role in explaining neighborhood effects on teachers' assessments. Teachers might ascribe positive or negative characteristics to students because students live in or the schools they visit is located in a neighborhood regarded by teachers as 'social purgatories' or 'penalized spaces' (Wacquant 1996, p. 125). This mechanism of discrimination in less favorable residential contexts stands at odds to general stereotype theory stressing the beneficial consequences of social or ethnic heterogeneity (Blau 1960, Zajonc 1968). 
Table 1: The state of research on effects of educational contexts on teachers' assessments

\section{Social composition}

\section{Hao \& Bonstead-Bruns}

(1998): Negative effect of $\%$

students eligible for free lunch

$$
\text { on GPA }
$$

Szulkin \& Jonsson (2007): Positive effect of $\%$ parent

with university degree

Marsh (1987): Negative effect of school-average SES on GPA

Tevis (2007): Positive effect of $\%$ free lunch on math and English grade

\section{Goza \& Ryabov (2009):}

Positive effect of school-leve

SES on GPA

Grades

\begin{tabular}{|c|c|c|c|}
\hline & $\begin{array}{l}\text { Ryabov (2011): Robust } \\
\text { positive effect of school- } \\
\text { average SES on grades }\end{array}$ & & \\
\hline & $\begin{array}{l}\text { Östh et al. (2013): Positive } \\
\text { effect } \% \text { highly educated } \\
\text { parents; negative effect \% } \\
\text { parents receiving social } \\
\text { benefits }\end{array}$ & & \\
\hline \multirow{3}{*}{$\begin{array}{l}\text { Judgments/ } \\
\text { expectations }\end{array}$} & $\begin{array}{l}\text { Ready \& Wright (2011): } \\
\text { Positive effects of class- } \\
\text { average SES on teachers' } \\
\text { perceptions of literacy skills }\end{array}$ & $\begin{array}{l}\text { Ready \& Wright (2011): } \\
\text { Negative effect of school- } \\
\text { average SES on teachers' } \\
\text { perceptions of literacy } \\
\text { skills }\end{array}$ & $\begin{array}{l}\text { Newman et al. (1989): } \\
\text { No effect of \% } \\
\text { disadvantaged in school } \\
\text { on teachers' } \\
\text { expectations }\end{array}$ \\
\hline & & $\begin{array}{l}\text { Agirdag et al. (2013): } \\
\text { Negative effect of school } \\
\text { SES composition on } \\
\text { individual teachability } \\
\text { expectations }\end{array}$ & \\
\hline & & $\begin{array}{l}\text { Brault et al. (2014): } \\
\text { Negative effect of school } \\
\text { SES composition } \\
\text { (mediated by achievement } \\
\text { composition) }\end{array}$ & $\begin{array}{l}\text { Meissel et al. (2017): No } \\
\text { effect of school SES } \\
\text { composition }\end{array}$ \\
\hline
\end{tabular}

Szulkin \& Jonsson

(2007): No effect of $\%$

on grades

Brännström (2008): No

effect of $\%$ social

assistance or parents

with university degree

on grades

on grade

rar

(

\section{o}

\begin{tabular}{l|l} 
& $\begin{array}{l}\text { Fekjaer \& Birkelund (2007): } \\
\text { Positive effect of ethnic } \\
\text { composition on grades }\end{array}$ \\
\hline to &
\end{tabular}

\begin{tabular}{|ll}
$\begin{array}{l}\text { Fekjaer \& Birkelund (2007): } \\
\text { Positive effect of ethnic } \\
\text { composition on grades }\end{array}$ & $\begin{array}{l}\text { Portes \& Hao (2004): } \\
\text { on GPA }\end{array}$ \\
\hline
\end{tabular}

Szulkin \& Jonsson (2007):

Szulkin \& Jonsson (2007):

Negative effect for $\% 1^{\text {st }}$

grades

Tevis (2007): Negative effect
of $\%$ Asians and Blacks on

math and English grade

Medina (2010): No effect of \%
immigrants in school on grades

(2)

Ryabov (2011): Negative
effect of $\%$ minority on

grades

Hermansen \& Birkelund (2015):

No effect of proportion

immigrants on grade

achievement

Brännström (2008): No effects

of $\% 1^{\text {st }}$ and $2^{\text {nd }}$ generation youth at school on grades

Muller et al. (2010): No effect of $\%$ Afro-American and

Hispanic Students in advanced math classes

\begin{tabular}{|c|c|c|}
\hline $\begin{array}{l}\text { Newman et al. (1989): Negative } \\
\text { effect of } \% \text { white in school on } \\
\text { teachers' expectations }\end{array}$ & & $\begin{array}{l}\text { Ready \& Wright (2011): No } \\
\text { effect of \% non-English } \\
\text { language background in class }\end{array}$ \\
\hline \multirow[t]{2}{*}{$\begin{array}{l}\text { McKown \& Weinstein (2008): } \\
\text { Positive effect of classroom } \\
\text { diversity on teachers' } \\
\text { expectations }\end{array}$} & $\begin{array}{l}\text { Agirdag et al. (2013): Lower } \\
\text { teachability expectations in } \\
\text { schools with higher share of } \\
\text { non-native students }\end{array}$ & \\
\hline & $\begin{array}{l}\text { Brault et al. (2014): Negative } \\
\text { effect of school ethnic } \\
\text { composition (mediated by } \\
\text { school climate) }\end{array}$ & $\begin{array}{l}\text { Meissel et al. (2017): No effect } \\
\text { of school ethnic composition }\end{array}$ \\
\hline
\end{tabular}


Social composition

$+$

\section{-}

Driessen et al. (2008):

Negative effect of $\%$ native

Boone et al. (2018):

Dutch disadvantaged in class

Negative effect of class-

SES composition

Gröhlich \& Guill (2009):

Positive effect of class-average

Track

HISEI

Schulze et al. (2009): Positive

effect of class- and school-
end

average SES

Timmermans et al. (2015):

Negative effect of \% low-

educated parents (class)

Bates and Glick (2013):

Positive effect of school title I.

founding on teachers'

assessments of students'

Stereotypes

externalizing behavior

Ethnic composition -

Driessen et al. (2008): No effect of $\%$ minority disadvantaged

Schulze et al. (2009): No effect of ethnic composition

Boone et al. (2018): No effect

of class ethnic composition

Glock et al. (2018): More $\quad$ Vervaet et al. (2016):

diverse schools: teachers hold

less negative attitudes about

students and are more

motivated to teach minority

students
Negative effect of ethnic

school composition on

teacher prejudice (but only

when controlled for

teachability

Glock et al. (2018): Teachers

think more effort is needed in

fictitious diversity condition
Bates \& Glick (2013): No significant effect of $\%$ minority

in student body on teachers'

assessments of students' externalizing behavior 
The empirical state of research on educational outcomes indicates a positive effect of favorable neighborhood conditions on students' achievement, aspirations, or attainment (e.g., Ainsworth 2002, Bowen and Bowen 1999, Brännström 2008, Flouri, Tsivrikos, Akhtar et al. 2015, Galster, Santiago, Stack et al. 2016, Garner and Raudenbush 1991, Harding 2011, Kauppinen 2008, Mayer and Jencks 1989, Owens 2010, Sampson, Morenoff and Gannon-Rowley 2002, Sewell and Armer 1966, Wilson 1987). There are a few studies investigating neighborhood effects on teacher discrimination of their students (Benner and Graham 2013, Hunt, Wise, Jipguep et al. 2007, Seaton and Yip 2009), but to the best of our knowledge, there is no research on neighborhood effects on teachers' judgments or expectations of their students.

\section{Institutions}

Not only the neighborhood as a potentially relevant context for teachers' assessments but also institutional settings (e.g., policies such as stratification) are understudied as potential determinants of teachers' judgments and expectations. Theoretically it can be argued that institutional preconditions are relevant in several ways: First, the degree of stratification can play a valid role in explaining teacher assessments. In particular, the timing of tracking and the extent to which the teacher is accountable for the track placement decisions may influence teachers' evaluations of their students. The earlier teachers are required to recommend a hierarchically differentiated ability track, the less time they have to assess their students. Consequently, the more likely it is that teachers rely on generalized stereotypes. This information deficit due to timely restrictions might contribute to the (re)production of social and ethnic inequality (Lamont 2012).

Empirically, it has been shown that social inequality in teachers' track recommendations is larger in earlytracking educational systems (Van de Werfhorst and Mijs 2010). Second, following theories of social cognition, a less flexible frame of decision making leads to a higher degree of accountability on the teacher side, which might make teachers more inclined to base their assessment on accurate information (Bandura 1986, Pit-ten Cate, Krolak-Schwerdt and Glock 2016). One example of accountability of teachers is the extent to which track recommendations are binding. For instance, in some German federal states and in parts of Belgium (Flanders), parents can decide whether they comply with the teacher's recommendation or deviate from it (Boone et al. 2018, Dollmann 2016). These non-binding settings reduce the liability of the teacher. Empirical findings based on (vignette) experiments suggests that a low accountability increases ethnic differences in performance ratings (Krolak-Schwerdt, Böhmer and Gräsel 2013) and decreases the accuracy of tracking decisions, especially for ethnic minority and immigrant students (Pit-ten Cate et al. 2016). 
Interrelation of contexts

Beyond the relevance of singular contexts, we argue that it is in particular the interrelation between contexts which might become relevant in understanding the formation of teachers' assessments. Cook (2003) summarized that social contexts might be interrelated in three different ways: additive if, for instance, neighborhood and school context jointly affect educational outcomes; substitutable if, for instance, the effect of neighborhood context vanishes once school context is controlled for (or vice versa), or multiplicative if, for instance, the effect of neighborhood context varies for different levels of school context (or vice versa). Moreover, educational contexts may not only be interrelated with one another, but also with individual-level characteristics. Empirical studies demonstrate that individuals with different social and ethnic origin maybe viewed differently by living in a deprived neighborhood (Flouri et al. 2015, Galster et al. 2016, Owens 2010).

While research on the effects of the interrelation of educational contexts on educational outcomes is a promising field of investigation, it has not been studied when analyzing teachers' assessments. Concerning students' educational achievement, some studies observed additive effects of neighborhood and school context on achievement: Catsambis and Beveridge (2001) noted simultaneous negative effects of neighborhood disadvantage and the school-level share of students eligible for free lunch on mathematics achievement. Ainsworth (2002) observed a positive relationship between the share of high-status residents in students' neighborhood and student achievement that persisted when controlled for several school characteristics. In contrast, both Card and Rothstein (2007) and Owens (2010) found substitutable effects. Here, a negative effect of school composition vanished once controlled for neighborhood composition. In addition, Owens (2010) emphasized that neighborhood and school context conditions can be even multiplicative. There are very few studies on the multiplicative effects of contextual conditions on educational outcomes. While the scope of our paper is the explanation of educational context conditions on teachers' assessments, it is worth exploring potential multiplicative relations between contexts for other educational outcomes as well.

\section{Theoretical model and hypotheses}

To provide a more comprehensive framework for the explanation of educational context effects on teachers' assessments, we argue that it is useful to draw on a dual-process approach (Lizardo et al. 2016, Miles et al. 2019, Vaisey 2009). The crucial assumption of dual-process models is that individuals deal with information along a continuum at the ends of which we find automatic-spontaneous processing on the one hand, and rationalcalculating processing on the other hand. The automatic way of information processing is also called system- 
1 processing as it is assumed that it is the 'default' mode (which is hard-wired by evolution) as long as the accessibility of mental categories allowing automatic processing is given. The system-1 mode is replaced by a rational processing mode, also referred to as system-2 processing, if the costs or the relevance of a decision are sufficiently high (Chaiken 1980, Fazio 1990). The rational processing mode is referred to in the many versions of sociological rational choice approaches (Hechter and Kanazawa 1997, Kroneberg and Kalter 2012). Dual process models assume that salient categories of social situations (e.g. the share of immigrant students in the classroom, or the image of a neighborhood) activate mental models or generic concepts that determine the dominant processing mode (e.g., Kroneberg and Kalter 2012). Basically, two different concepts can be distinguished that broadly map functionally equivalent ideas: framing approaches and schema theory. Frames are mental models of social situations. Although subjective, even erroneous mental models may be relevant. In one of the most famous wordings on this phenomenon, Thomas and Thomas pointed out that '[i]f men define situations as real, they are real in their consequences' (Thomas and Thomas 1928, p. 571f.). Goffman (1974) defined frames as socially acquired perceptual schemes that facilitate to unveil the 'sense' of social situations by an unconscious process. ${ }^{1}$ A conceptually related approach is schema theory (e.g., McVee, Dunsmore and Gavelek 2005). Schemes represent the generic concepts stored in memory and 'exist for generalized concepts underlying objects, situations, events, sequences of events, actions, and sequences of actions' (Rumelhart and Ortony 1977, p. 1). Thus, while frames have been more closely tied to social situations, schemes could also comprise models of consecutive actions.

The common denominator of both framing and schema theory is that salient categories in social situations can activate an automatic or a rational cognitive processing style (e.g., Kroneberg and Kalter 2012). Following those general theoretical arguments, we assume that beyond attributes of students, the social and ethnic composition of educational contexts constitute salient categories which facilitate teachers' more automatic processing when forming assessments of their students. Empirically, it has been shown that even expert judgment and decision-making often relies on automatic processing (Evans 2008). Teachers are undoubtedly experts for the assessment of student achievement. Coburn (2004) $\square$ suggests that teachers are framed by preexisting cognitive frameworks, called worldviews, which they have acquired in past social interactions. Previous research has convincingly demonstrated that classroom and school context conditions constitute salient categories which frame various forms of teachers' assessments over and above student characteristics

1 Comparing the framing approach with symbolic interactionism, frames constitute the structures underlying individuals' everyday definition of social situations (Gonos 1977). 
such as social or ethnic background (for an extensive overview, see table 1). Ellen (2000) demonstrates that race-based stereotypes - which are mental models about characteristics or behavior of ethnic groups - are not limited to individual-level categories but can expand towards the neighborhood. Consequently, over and above mental models about classroom and school characteristics, teachers can additionally be framed by situational cues of the neighborhood (e.g., 'black, 'dangerous' or 'poor') when evaluating their students (Morris 2005). Hence, although students' performance and educational motivation can be expected to be most relevant for teachers' expectations, it is reasonable to suggest that context conditions additionally matter.

To deduce directed hypotheses for all contextual levels, we adopt a framing perspective on the idea of interrelatedness of educational contexts (Cook 2003). For a long time, framing theory has been limited to the analysis of one single frame. Yet, it is more and more acknowledged that frames could be simultaneous or even contradictory (Vliegenthart and Zoonen 2011). In case of simultaneous or additive frames of educational contexts conditions, two frames on the same or different levels can automatically affect teachers' assessments of their students at the same time while situational context conditions determine the relative strength of each frame.

Social composition effects on teachers' assessments simultaneously operate either via positive Halo effects by which teachers' attribute the beneficial social composition of a context to a particular student, or by negative Grading-on-a-Curve effects by which teachers increase their academic standards in more favorable learning environments. In previous research (for an extensive overview, see table 1), positive Halo effects are stronger on the classroom than on the school level. This could be due to the fact that the classrooms' social composition is in line with teachers' perceived classroom climate or teachability judgments which in more favorably composed classrooms directly influence teachers' expectations of their students.

Similarly, ethnic composition effects simultaneously operate via frames of negative context-based ethnic stereotypes and positive exposure effects which at the same time reduce ethnic stereotypes and prejudices. As table 1 suggests, some studies point in one, some into the other direction. Unlike for social composition effects, no study simultaneously modeled several contexts. Hence, it is still possible that observed effects on a given level are conflated by unobserved effects on a neglected level. Also, distributional effects might be at stake as the two studies which observe positive diversity effects of schools' ethnic composition are from the US where schools are considerably more ethnically segregated.

For social composition effects, we expect either positive Halo effects for classroom and school level or 
negative Grading-on-a-Curve effects. For neighborhood effects, the state of research on achievement- and motivation-related educational outcomes suggests harmful effects of a disadvantageous social composition. Yet, analogously to school- and classroom-level composition, teachers might assess their students against the perceived academic capability of the neighborhood - which is why negative Grading-on-a-Curve effects would also be possible. For the immigrant composition, we expect negative context-based stereotypes for our ethnically less segregated classroom, neighborhoods and school contexts. In line with frame-of-reference theory, classrooms are the most proximal context in which teachers actively operate on a daily basis (Liem, Marsh, Martin et al. 2013, Marsh, Kuyper, Morin et al. 2014). Hence, we expect theoretically that classroom conditions constitute the most salient frame. As a consequence, neighborhood and school effects should be at least partially mediated (i.e., decrease or vanish) by corresponding classroom effects. From these assumptions, the following hypotheses can be deduced:

H1a: Teachers' expectations of their students can either be positively influenced by an advantageous social composition of classrooms, schools and neighborhoods (Halo effect, socialization, role model) or be negatively influenced (Grading-on-a-Curve effect, relative deprivation).

H1b: Teachers' expectations are negatively influenced by a higher share of immigrants in classrooms, schools and neighborhoods (context-based ethnic stereotyping).

H1c: Neighborhood and school effects on teachers' expectations are mediated by corresponding classroom effects (salience of frames).

While in the first step (Hypotheses 1a and 1b) we have carved out the explanatory value of framing theory for additive and substitutable interrelations, in a second step, we advance our framing perspective on multiplicative interrelations of educational contexts which have been analyzed only sporadically (Owens 2010, Weßling et al. 2015). Thus, the framing approach can borrow from schema theory which has postulated the possibility of an embeddedness of schemas within one another (McVee et al. 2005, p. 537). Concretely, we expect that educational context conditions on different levels constitute multiple frames that may be interrelated. Similar to our first hypothesis, either positive reinforcement or negative attenuation effects may be possible. On the one hand, it might be that categories which are closely related to one another but situated on different levels - such as the social composition of classrooms, schools, and neighborhoods - evoke automatic framing effects that reinforce one another. On the other hand, educational context conditions may affect teachers' expectations by social mechanisms exerting empirical effects which are positive on one level but negative on the other. Consequently, in opposition to a pure reinforcement of positive or negative effects, 
we might also expect an attenuation of effects of educational context conditions on teachers' expectations across levels. Thus, we deduce the following hypotheses:

H2a: We predict either a reinforcement or an attenuation of social composition effects on the level of classrooms, schools and neighborhoods.

H2b: We predict a reinforcement of immigrant composition effects on the level of classrooms, schools and neighborhoods.

In a third step, we additionally explore the role of institutional contexts for framing effects on teachers' assessments. Following a basic argument of framing theory, we derive that effects of contexts will depend on (teachers') situational costs. From dual-process models, we have already outlined that the relevance or costs associated with a decision at hand may shift information processing from more automatic to more rational processing (Chaiken 1980, Fazio 1990). For our research question, the institutional setting of the educational system constitutes a relevant condition that will determine how much relevance teachers associate with their assessments. We argue that a higher degree of accountability might make teachers judgments and expectations more deliberate (Bandura 1986, Pit-ten Cate et al. 2016). In tracked education systems such as the German, teachers are obliged to communicate track recommendations for secondary school at the end of elementary school. However, the extent to which these track recommendations are binding varies across German federal states. We assume that in binding institutional settings, teachers associate more relevance even to informal assessments collected by survey questions. In sum and more generally, these considerations lead us to hypothesize:

H3: Positive or negative effects of the social and immigrant context composition on the three contextual levels (classrooms, schools, neighborhoods) on teacher' expectations are attenuated or disappear when teachers' perceived relevance of their expectations is high (i.e., binding recommendation for secondary school track).

\section{Data and methods}

\section{The case of Germany}

We opt for Germany as an interesting case to study teachers' expectations of elementary school students for two reasons: First, the German school system represents an exemplary case of a tracked education system (Hallinan 1994), characterized by mostly rigorous and early tracking (von Below, Powell and Roberts 2013).

This early tracking has far-reaching consequences for education and labor market prospects (Van de 
Werfhorst and Mijs 2010). After four years of elementary school education, students are separated into three (sometimes two) hierarchically structured types of secondary schools. Teachers and their expectations about their students play an important role in this sorting process, especially because teachers are responsible for recommending the secondary school track. Second, federal countries such as the United States or Germany allow for institutional variation in the specification of the educational system within one country. We exploit this institutional variation to test the assumption that teachers' expectations are less likely to be influenced by contextual conditions such as classrooms or neighborhoods when the institutional preconditions lead to teachers' expectations being more relevant and consequential. Each of the 16 German states is responsible for specifying the transitions process from elementary to secondary school (Freitag and Schlicht 2009). One particular difference between states is in the role that teachers and subsequently parents play in the track placement. Unlike other early tracking countries such as the Netherlands or Belgium, there is no standardized test to determine the type of secondary school track. The decision lies either with the teacher (binding recommendation), or the teacher gives a recommendation which can be overruled by parents (non-binding recommendation). In a quasi-experimental setting that involved a reform from non-binding to binding recommendations in one German federal state, Dollmann (2016) shows that reducing parents' leeway to decide about school tracks diminishes social and increases ethnic inequalities at the transition to secondary education.

At the time of recommendation in our survey (2016), there are four federal states in which the recommendation can be considered binding, while there are twelve states with a non-binding recommendation. ${ }^{2}$ Thus, this institutional feature can be viewed as a key indicator for how far-reaching the consequences are that result from the teacher's assessment of his/her students.

We carry out robustness analyses for two other institutional features that differ between federal states indicating a similar mechanism: We differentiate between school systems that offer a comprehensive school alongside the three hierarchically structured secondary school tracks. The idea is that the sorting into tracks can be bypassed by entering comprehensive secondary school. There are currently seven states which offer this alternative. The existence of this alternative implies the possibility to postpone or avoid the decision for a hierarchically secondary school track. Hence, the elementary school teacher's recommendation becomes

2 Binding recommendation: Bavaria, Brandenburg, Saxony, Thuringia. Schleswig-Holstein has an intermediate position because the recommendation is non-binding; however, no child with a recommendation for the lowest track (Hauptschule) can enter the highest track. Results do not change with and without considering Schleswig-Holstein for our measure of bindingness. 
less relevant. Beyond that, we differentiate between federal states in which an orientation phase or prolonged elementary school is available. The orientation phase postpones the track decision from 4th to 6th grade. There are four federal states that provide either six years of elementary school or an orientation phase, most of them in the Eastern part of Germany. To assess whether the differences we find are due to institutional regulations in federal states and not due to other differences, we additionally test a wide set of regional variables on the state level such as: Eastern versus Western Germany, urban versus rural contexts, large states versus city states, economically weak versus strong regions.

\section{Data}

We use data from the German National Educational Panel Study - Starting Cohort 2 (NEPS-SC2; Blossfeld, Roßbach and von Maurice 2011). ${ }^{3}$ The data set provides extensive information on elementary school students and their parents, teachers, as well as on the classroom and school composition. NEPS-SC2 is most suitable to study teachers' expectations because teachers are asked to assess their students' educational prospects on a yearly basis. The binary dependent variable distinguishes between teachers' expectations for a student to (1) attend and accomplish the academic secondary track versus (2) not attend and graduate from academic secondary school. It is measured in three consecutive years in elementary school from second to fourth (last) grade, in which the main teachers are asked about their expectations of their students' educational prospects. The specific question is: 'In your opinion, which school-leaving qualification would this child be most likely to obtain from today's perspective?

The independent variables that we are most interested in are information on the composition of classrooms, schools, neighborhoods, and institutional conditions. On the classroom and school level, we include information on the share of both high-SES children and immigrants which originally stems from the teacher (classroom) and school principal (school) questionnaire. In case of missing information, values have been filled up by aggregated information derived from the parental questionnaire if information is available for more than three students in the same school class. Information on the neighborhood in which the school is

3 This paper uses data from the National Educational Panel Study (NEPS): Starting Cohort 2 - Kindergarten, doi:10.5157/NEPS:SC2:6.0.1. From 2008 to 2013, NEPS data were collected as part of the Framework Programme for the Promotion of Empirical Educational Research funded by the German Federal Ministry of Education and Research (BMBF). As of 2014, the NEPS survey is carried out by the Leibniz Institute for Educational Trajectories (LIfBi) at the University of Bamberg in cooperation with a nationwide network. 
located is measured on a level smaller than zip-code areas (PLZ8-level), which consist on average of 500 households (Schönberger and Koberg 2016). It is possible to link NEPS-SC2 to neighborhood information from microm consumer marketing (Schönberger and Koberg 2016). Microm consumer marketing holds extensive information about the socio-structural composition of small-scale residential areas such as the share of foreigners, the purchasing power, the age structure or the unemployment rate. This data is available for both the residential area in which the students live as well as the residential area in which the elementary school is located. We use data on school areas since we are interested in whether the environment in which the school is located affects teachers' perceptions. To capture the immigrant composition of the neighborhood we use the share of foreigners. Microm consumer marketing analyses first and last names from registers to derive this information. The variable ranges from 1 (low share) to 9 (high share). To capture the socioeconomic conditions of the schools' neighborhood we built a factor score variable measuring the aggregate social status in the neighborhood consisting of social status, unemployment rate, and purchasing power in the neighborhood. The social status variable enables a classification according to income and education and ranges from 1 (lowest status) to 9 (high status). Purchasing power includes all forms of income from labor, capital assets, and renting after deduction of taxes and social security contributions. In addition, benefits such as child benefit, unemployment benefits or pensions are added. The unemployment rate is an indicator by the Federal Employment Agency. It is important to note that the composition of school neighborhoods is both analytically and empirically different from a neighborhood-level aggregation of students' social or migration background for three reasons: first, students do not necessarily live in the immediate neighborhood of their schools; second, the operationalization of neighborhood (plz-8 area comprising on average 500 households) leaves us with an area that is on average smaller than the typical catchment area of a school; third, neighborhoods in general are not only composed of residents with schoolage children.

Evidently, the most important control variable is a measure of students' performance. In addition to grades, which are given by teachers and therefore not well suited to measure students actual aptitude, independent and repeated performance tests are carried out by the NEPS. In particular, we control for students' performance test scores in mathematics. We use mathematics performance because it is more stable and of higher predictive validity for students' educational success than language-based performance indicators. Also, it is the only performance variable that measures the same latent construct across all three time points of measurement. Beyond that, we include students' aspirations as an indicator of how motivated or ambitious students are. Also, we control for a wide set of other student, parent, and teacher characteristics which might be potential confounders of contextual-level effects on teachers' expectations. An overview of all variables 
that are included in our model can be found in Table 2.

NEPS-SC2 provides information on 9,337 students across their elementary school career. However, due to panel attrition as well as missing data for parents, teachers ${ }^{4}$, school principals, and neighborhood information, and also due the fact that for the multilevel panel models to follow, we only considered school classes with at least three students, we have an analysis sample with 3,597 observations (1,199 students) at hand. Since our data contains only one school per neighborhood, neighborhood information is modeled on the school level. However, we have an extensive set of variables to capture the composition of neighborhoods, schools, and classrooms separately. To illustrate that the socio-structural composition of classroom, school and neighborhood differ, we provide correlations between the contextual variables on all three levels in Table A1 in the appendix.

4 Where possible, missing teacher information (gender, migration background, seniority) were replaced by information from the first wave in elementary school. This was of course only possible for schools where the teacher did not change. In classrooms with more than five students, missing information on the classroom is replaced by multiple imputation MI using both information on the school level as well as aggregated parental information level. The results between models with and without imputed cases do not differ substantively. 
Table 2. Descriptive statistics. Data: NEPS-SC2, microm consumer marketing

\begin{tabular}{|c|c|c|}
\hline & $\begin{array}{l}\text { Teachers' expectation: } \\
\text { no gymnasium } \\
\% \text { / x;(std);[min-max] }\end{array}$ & $\begin{array}{l}\text { Teachers' } \\
\text { expectation: } \\
\text { gymnasium } \\
\% \text { / x;(std);[min-max] }\end{array}$ \\
\hline \multicolumn{3}{|l|}{ NEIGHBORHOOD $(n=161)$} \\
\hline SES: Status index (unemployment, purchasing power, social status) & $0.4 ;(1.7) ;[-6-3.2]$ & $0.5 ;(1.8) ;[-5.1-3.2]$ \\
\hline Migration: foreigners $(1=$ low- $9=$ high $)$ & $4.3 ;(2) ;[1-9]$ & 5.2;(2.2);[1-9] \\
\hline \multicolumn{3}{|l|}{ SCHOOL $(n=161)$} \\
\hline SES: $\%$ of high SES & $19.7 ;(13.1) ;[0-75]$ & $22.1 ;(15.3) ;[0-75]$ \\
\hline Migration: $\%$ of immigrant background & $23.1 ;(19) ;[0-91]$ & $23.4 ;(18.9) ;[0-91]$ \\
\hline \multicolumn{3}{|l|}{ CLASSROOM } \\
\hline SES: $\%$ of high SES & $19.9 ;(13.9) ;[0-94]$ & 22.4;(15.8);[0-94] \\
\hline Migration: $\%$ of immigrant background & $24 ;(21.2) ;[0-100]$ & 26.3;(21.3);[0-100] \\
\hline \multicolumn{3}{|l|}{ TEACHER $(n=235)$} \\
\hline Female teacher (ref.: male) & $47.7 \%$ & $52.3 \%$ \\
\hline Migration background teacher (ref.: no mig. backgr.) & $45.6 \%$ & $54.4 \%$ \\
\hline Seniority teacher (less than 5 years) & $51.2 \%$ & $48.8 \%$ \\
\hline Seniority teacher ( 5 - less than 10 years $)$ & $48 \%$ & $52 \%$ \\
\hline Seniority teacher (10 - less than 20 years $)$ & $46.3 \%$ & $53.7 \%$ \\
\hline Seniority teacher (more than 20 years) & $47.7 \%$ & $52.3 \%$ \\
\hline Teacher exam grade (1-4) & $2.1 ;(1.2) ;[1-4]$ & $2.0 ;(1.2) ;[1-4]$ \\
\hline \multicolumn{3}{|l|}{ STUDENT $(n=1,199)$} \\
\hline Female student (ref.: male) & $45.6 \%$ & $54.4 \%$ \\
\hline Migration background student (ref.: no mig.backgr.) & $61.7 \%$ & $38.3 \%$ \\
\hline Parents' combined max. ISEI & $46.2 ;(18.4) ;[14.2-88.9]$ & $68.8 ;(18.1) ;[14.2-88.9]$ \\
\hline Students' idealistic aspiration: academic track (ref.: no academic track) & $41.6 \%$ & $58.4 \%$ \\
\hline Students' performance test scores (mathematics) & $3.2 ;(1.3) ;[-1.3-7.3]$ & 4.2;(1.3);[-.9-9.4] \\
\hline Teacher changed (ref.: same teacher) & $46.2 \%$ & $53.8 \%$ \\
\hline \multicolumn{3}{|l|}{ INSTITUTIONAL REGULATION } \\
\hline Binding recommendation (ref.: non-binding) & $50.4 \%$ & $49.6 \%$ \\
\hline Comprehensive Schools available (ref.: no compreh.) & $46.1 \%$ & $53.9 \%$ \\
\hline Two-year orientation phase (ref.: no orientation) & $45.9 \%$ & $54.1 \%$ \\
\hline \multicolumn{3}{|l|}{ OBSERVATION POINTS $(n=3,597)$} \\
\hline 2nd grade & $47.9 \%$ & $52.1 \%$ \\
\hline 3rd grade & $49.3 \%$ & $50.7 \%$ \\
\hline 4th grade & $45.5 \%$ & $54.5 \%$ \\
\hline Overall & $47.6 \%$ & $52.4 \%$ \\
\hline
\end{tabular}

\section{Estimation strategy}

In the multivariate analyses, we apply a multilevel panel model (Singer and Willett 2003). It considers the panel structure of our data in treating observations over time as the lowest level of analysis which are nested 
in students on the second level. Concretely, for three time points in elementary school - from second grade (children aged 7 or 8 ) until fourth grade (children aged 9 or 10) - teachers' expectations on their students are queried. The three observation points are nested in students, which are nested in classrooms, which are nested in schools and neighbourhoods. We take into account that the main teachers, who report on their expectations of students, can change over the course of elementary school, which is why the underlying data structure is cross classified. To test our hypotheses, we apply linear probability models (LPMs) in a threelevel cross-classified model (e.g., Hox 2010, ch. 9). A concern of LPMs is that they violate the homoscedasticity assumption. Beyond that, LPMs are not constraint to the unit interval between 0 and 1 as this is the case in logit or probit approaches. To address the LPM's shortcomings, we calculate heteroscedasticity-robust standard errors. Following Horrace and Oaxaca (2006), we check for observations that produce predicted probabilities outside the range of zero to one. ${ }^{5}$ In Figure 1 an overview of the data structure is provided. Technically, students are hierarchically nested in school neighbourhoods. Yet, as said, neighbourhood social and migration composition is substantially different from what would have been obtained had we aggregated student-level social and migration background on the level of neighbourhoods.

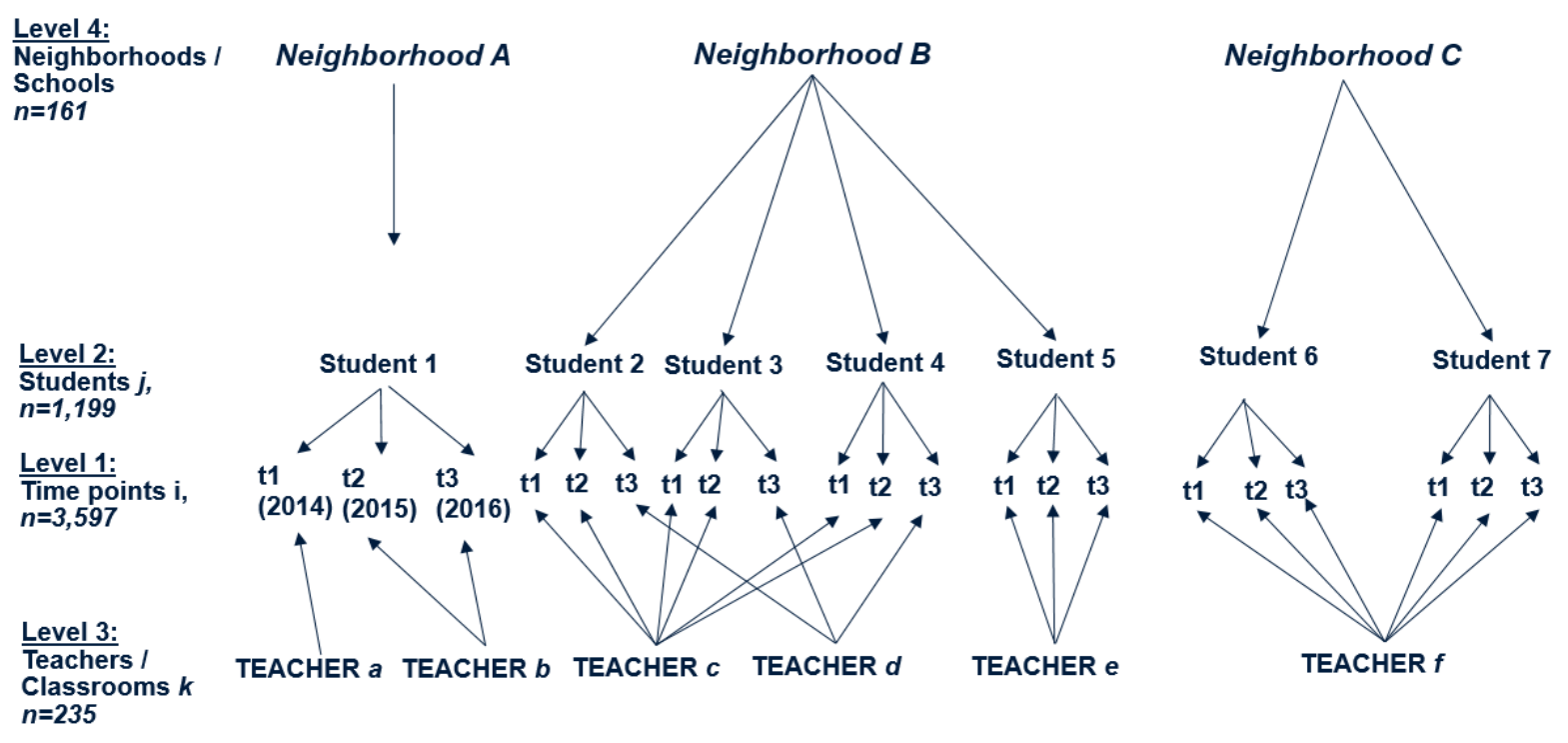

Figure 1. Multilevel data structure. Data: NEPS-SC2, microm consumer marketing.

5 The LPMs presented include only observations that produce predicted probabilities between zero and one. A total of $3 \%$ cases produce predicted values below zero or above one, but we observe no differences in substantive findings. 


\section{Analytical results}

In Table 3 the results from the multilevel model are displayed. We differentiate six stepwise built up models. Model 1 is the null model without substantive variables, and only the baseline variable represented by the school year is included. We calculated the statistical effects of substantive variables on the three context levels - classroom (Model 2), school (Model 3), and neighborhood (Model 4) - separately. In Model 5, all three contextual levels are integrated simultaneously, and in Model 6 we add control variables for students, parents and teachers.

In Model 2, we find small but significant relations between the classroom social and migration composition and teachers' expectations, both associations are positive. Model 3 comprises estimates for the school level. Here, only the share of high-SES students is positively associated with teachers' expectations, but there is no significant coefficient for the migration composition of the school. In Model 4, we find that neighborhood deprivation is negatively, and the share of foreigners positively associated with teachers' expectations on their students to attend and succeed in the academic secondary school track. Without further controls these effects of the neighborhood are significant.

Linking these preliminary findings to theory, we find limited support for our hypotheses: Classroom, school and neighborhood social composition seem to frame teachers' automatic assessments via the mechanism of a Halo effect in that regardless of their own social background, students benefit from finding themselves in classrooms, schools or school neighborhoods with an advantageous social composition. However, in contrast to the hypothesized mechanisms, a higher share of students of foreign origin or with migration background in neighborhoods and classrooms appear to provoke that teachers hold higher expectations of their students. The corresponding estimate on the school level lacks statistical significance. Thus, we neither find support for the mechanism of a contrast effect between schools' social composition and teachers' assessment, nor for teachers' being framed via contextual-level ethnic stereotypes. Since this positive relation between the share of immigrant/foreign children and teachers' expectations seemed rather unexpected, we carried out some more in-depth analysis to understand this finding better (see below, figure 2).

Comparing the $\mathrm{AIC}$ and $\mathrm{BIC}$ between neighborhood, classroom and school model, we find the statistical explanatory power of the classroom model to be overall better, indicating that - comparing the three context levels - most variance in the dependent variable is explained by the classroom level. This is in line with arguments from frame-of-reference theory assuming that classrooms are the most proximal context in which teachers actively operate on a daily basis (Liem et al. 2013, Marsh et al. 2014). Educational context 
characteristics on all three contextual levels are modeled simultaneously in Model 5. The two contextual variables that show a significant (yet substantially counterintuitive) association with teachers' assessments are the share of non-native students in the classroom and the share of foreigners in the neighborhood. In contrast, the coefficient for school's social composition disappears once indicators of the two other contextual levels are modeled. Although controls for individual-level characteristics are yet to add, this might indicate that characteristics of school neighborhoods have a higher salience for teachers when forming their assessments of students than have attributes on the level of schools. In other words, while classroom and neighborhood context appear to exert additive influences, the relation between school social composition and the two other contextual levels appear to be substitutable.

In a next step (Model 6), we include a large set of control variables on teachers, parents, and students. The model indicates that none except one estimate of the educational context characteristics remains statistically different from zero. Adding these variables successively reveals that the largest part of the observed attenuation of contextual-level estimates can be attributed to students' immigrant background and parents' SES (available upon request). The only remaining significant and positive association is between the share of immigrant students in the classroom and teachers' expectations. The probability that teachers expect their students to succeed in the academic track is increased by 0.002 percentage points if the share of immigrants in the classroom is increased by 1 percent. Although rather limited in magnitude, this estimate indicates that the probability of expecting a student to attend the academic track is 0.2 percentage points higher in a classroom with 100 percent immigrants compared to 0 percent immigrants, holding every thing else constant. We tested several alternative modeling specifications - such as using language instead of mathematics performance, including the average performance composition of the classroom in mathematics and language, and only including school classes where we observe at least five students (instead of three) - all of which did not affect the stability of the positive association between the share of immigrants in the classroom and teachers' expectations (available upon request). 
Table 3. Cross-classified three-level analyses of teachers' expectations of elementary school students. Data: NEPS-SC2, microm consumer marketing

\begin{tabular}{|c|c|c|c|c|c|c|c|c|c|c|c|c|}
\hline \multirow{2}{*}{$\begin{array}{l}\text { MODELS } \\
\text { NEIGHBORHOOD }\end{array}$} & \multicolumn{2}{|c|}{ 1) Null model } & \multicolumn{2}{|c|}{ 2) Classroom model } & \multicolumn{2}{|c|}{ 3) School model } & \multicolumn{2}{|c|}{$\begin{array}{l}\text { 4) Neighborhood } \\
\text { model }\end{array}$} & \multicolumn{2}{|c|}{ 5) Context model } & \multicolumn{2}{|c|}{ 6) Full model } \\
\hline & & & & & & & & & & & & \\
\hline SES: Status index (unemployment, purchasing power, social status) & & & & & & & $0.007 *$ & 0.002 & 0.005 & 0.005 & -0.005 & 0.007 \\
\hline migration: foreigners $(1=$ low $-9=$ high $)$ & & & & & & & $0.019 * *$ & 0.007 & $0.007 *$ & 0.003 & 0.006 & 0.004 \\
\hline \multicolumn{13}{|l|}{ SCHOOL } \\
\hline SES: $\%$ of high SES & & & & & $0.003 *$ & 0.001 & & & 0.003 & 0.002 & 0.001 & 0.002 \\
\hline migration: $\%$ of immigrant background & & & & & 0.005 & 0.006 & & & 0.001 & 0.001 & 0.001 & 0.001 \\
\hline \multicolumn{13}{|l|}{ CLASSROOM/TEACHER } \\
\hline SES: $\%$ of high SES & & & $0.002 *$ & 0.001 & & & & & 0.002 & 0.001 & 0.002 & 0.001 \\
\hline migration: \% of immigrant background & & & $0.003 * *$ & 0.001 & & & & & $0.002 * *$ & 0.001 & $0.002 * *$ & 0.001 \\
\hline Female teacher (ref. male) & & & & & & & & & & & 0.007 & 0.055 \\
\hline Migration background teacher (ref. no mig. backgr.) & & & & & & & & & & & -0.017 & 0.03 \\
\hline Seniority teacher $(5-<10$ years) (ref. $<5$ years) & & & & & & & & & & & 0.007 & 0.055 \\
\hline Seniority teacher $(10-<20$ years $)$ (ref. $<5$ years) & & & & & & & & & & & -0.013 & 0.051 \\
\hline Seniority teacher $(>20$ years) (ref. $<5$ years) & & & & & & & & & & & $-0.005^{*}$ & 0.002 \\
\hline Teacher exam grade & & & & & & & & & & & 0.029 & 0.018 \\
\hline \multicolumn{13}{|l|}{ STUDENT } \\
\hline Female student (ref. male) & & & & & & & & & & & $0.070 * *$ & 0.022 \\
\hline Migration background student (ref. no mig.backgr.) & & & & & & & & & & & $-0.169 * *$ & 0.061 \\
\hline Parents' combined max. ISEI & & & & & & & & & & & $0.005 * * *$ & 0.001 \\
\hline Students' idealistic aspiration: academic track (ref. no academic track) & & & & & & & & & & & $0.254 * * *$ & 0.034 \\
\hline Students' performance test scores (mathematics) & & & & & & & & & & & $0.122 * * *$ & 0.009 \\
\hline Teacher changed (ref. same teacher) & & & & & & & & & & & -0.055 & 0.029 \\
\hline \multicolumn{13}{|l|}{ INSTITUTIONAL REGULATION } \\
\hline Binding recommendation (ref. non-binding) & & & & & & & & & & & 0.037 & 0.021 \\
\hline $3^{\text {rd }}$ grade (ref. $2^{\text {nd }}$ grade) & -0.007 & 0.013 & -0.015 & 0.013 & -0.008 & 0.015 & -0.007 & 0.013 & -0.051 & 0.027 & $-0.152 * * *$ & 0.019 \\
\hline $4^{\text {th }}$ grade (ref. $2^{\text {nd }}$ grade) & $0.034 * *$ & 0.013 & $0.022 *$ & 0.009 & $0.028 * *$ & 0.010 & $0.034 * *$ & 0.013 & $0.025 * *$ & 0.01 & $-0.238 * * *$ & 0.025 \\
\hline Var. (id.) & $0.100 * * *$ & 0.015 & $0.097 * * *$ & 0.016 & $0.097 * * *$ & 0.016 & $0.099 * * *$ & 0.015 & $0.082 * * *$ & 0.016 & $0.372 * * *$ & 0.019 \\
\hline Var. (neighborhood) & $0.064 * * *$ & 0.031 & $0.047 * * *$ & 0.041 & $0.050 * * *$ & 0.035 & $0.055 * * *$ & 0.032 & $0.039 * * *$ & 0.033 & $0.038 * * *$ & 0.035 \\
\hline Var. (time) & $0.387 * * *$ & 0.01 & $0.386 * * *$ & 0.011 & $0.385 * * *$ & 0.01 & $0.386 * * *$ & 0.01 & $0.353 * * *$ & 0.01 & $0.194 * * *$ & 0.01 \\
\hline Var. (resid) & $0.293 * * *$ & 0.04 & $0.294 * * *$ & 0.005 & $0.293 * * *$ & 0.005 & $0.293 * * *$ & 0.004 & $0.299 * * *$ & 0.005 & $0.198^{* * *}$ & 0.005 \\
\hline $\mathrm{AIC}$ & $3,717.8$ & & $3,331.42$ & & $3,643.2$ & & $3,713.19$ & & $3,290.76$ & & $2,023.18$ & \\
\hline $\mathrm{BIC}$ & $3,761.12$ & & $3,385.97$ & & $3,701.98$ & & $3,768.88$ & & $3,216.72$ & & $2,194.25$ & \\
\hline $\mathbf{N}$ & \multicolumn{2}{|l|}{3,597} & \multicolumn{2}{|l|}{3,597} & \multicolumn{2}{|l|}{3,597} & \multicolumn{2}{|l|}{3,597} & \multicolumn{2}{|l|}{3,597} & \multicolumn{2}{|l|}{3,597} \\
\hline
\end{tabular}


As mentioned above, the direction of this statistical effect comes as a surprise, since we would have expected that by the mechanism of contextual-level ethnic stereotyping, a higher share of students with immigrant background should reduce teachers' assessments of their students. By estimating an interaction between the classroom migration composition and students' individual migration background, we test whether the coefficient for classroom migration composition is statistically different from zero for different groups of students. Results can be found in Figure 2.

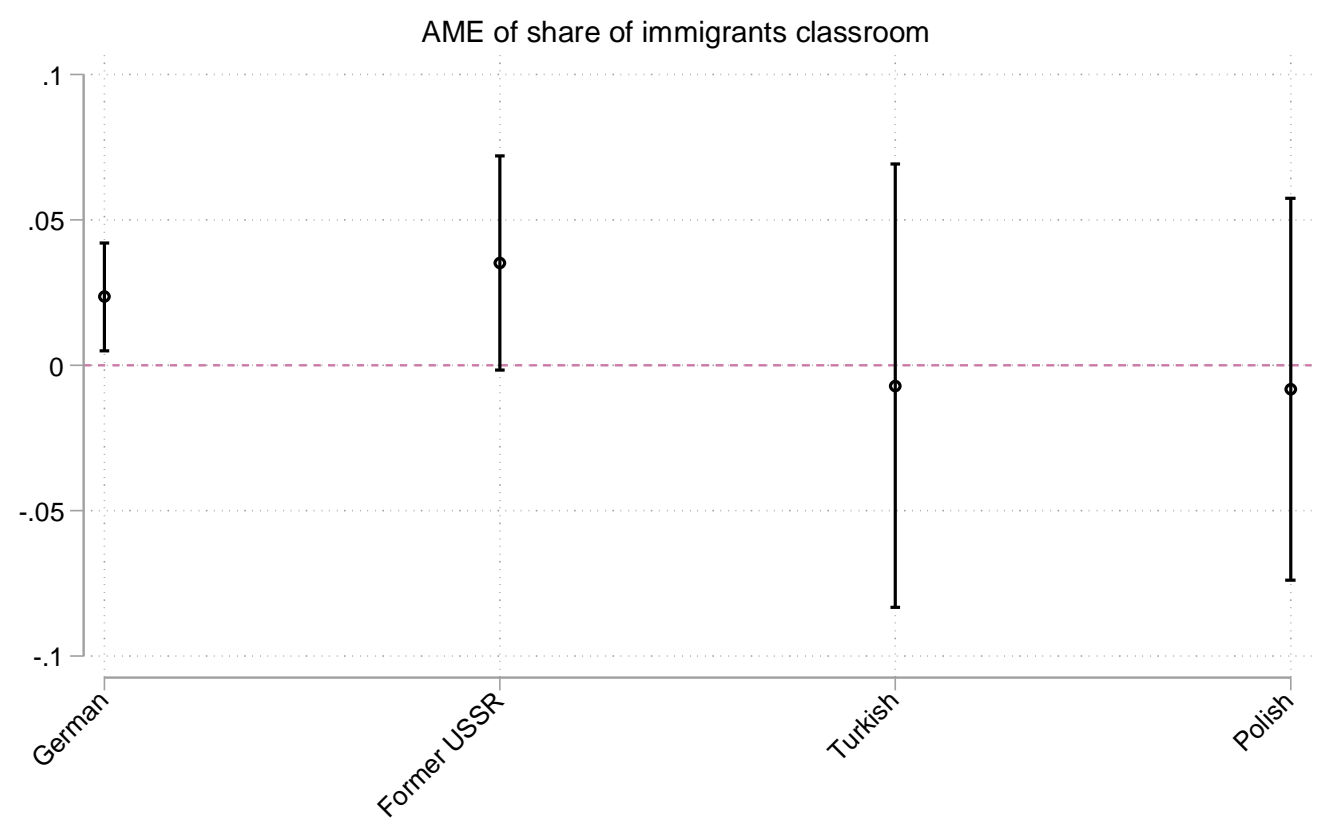

Students' migration background

Figure 2. Interaction between share of immigrants in classroom and students' individual migration background. Data: NEPS-SC2, microm consumer marketing.

The figure displays average marginal effects and we find the estimate of the share of students with immigrant background in the classroom to be significantly different from zero for native students only. The coefficient for students from former USSR background points in the same direction and does not significantly differ from the one for native students. However, this estimate is not significant. For the other two groups students from Turkish and Polish descent - we find negative associations, yet not significant and not statistically different from the other two groups. However, for German students we cannot reject the null hypothesis that the observed association is merely due to random error. Thus, we can conclude that teachers are likely to show higher expectations for German students, the higher the share of immigrant students in 
the classroom. This finding indicates a relative advantage for native students if more students of immigrant descent are in the same school class. It could be argued that native students are more likely to stick out and be visible to the teacher. Overall, this finding can be interpreted as tentatively in favor of our first hypothesis (1b) in which we stated that the immigrant composition on classroom, school, and/or neighborhood level affects teachers' assessments of their students. This association holds for the classroom-level share of immigrants after controlling for a wide set of variables, yet it only applies to native students.

In the second set of hypotheses ( $2 \mathrm{a}$ and $\mathrm{b})$, we argued that educational context conditions on different levels constitute multiple frames that may be interrelated to one another. Drawing on the argument of stereotypematching advantage, we postulated that conceptually close categories on different levels lead to mutually reinforcing contexts. In line with our assumptions, classroom conditions are the most prevalent; therefore, we present interaction effects of the share of high SES students and the share of immigrant students in the classroom for selected values of neighborhood and school composition in figure 3.

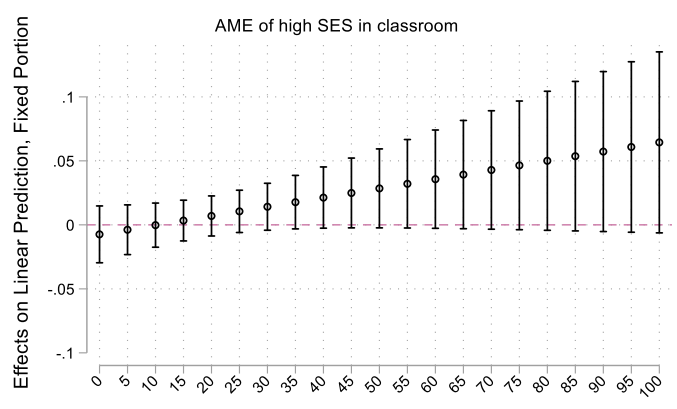

Share of high SES in school
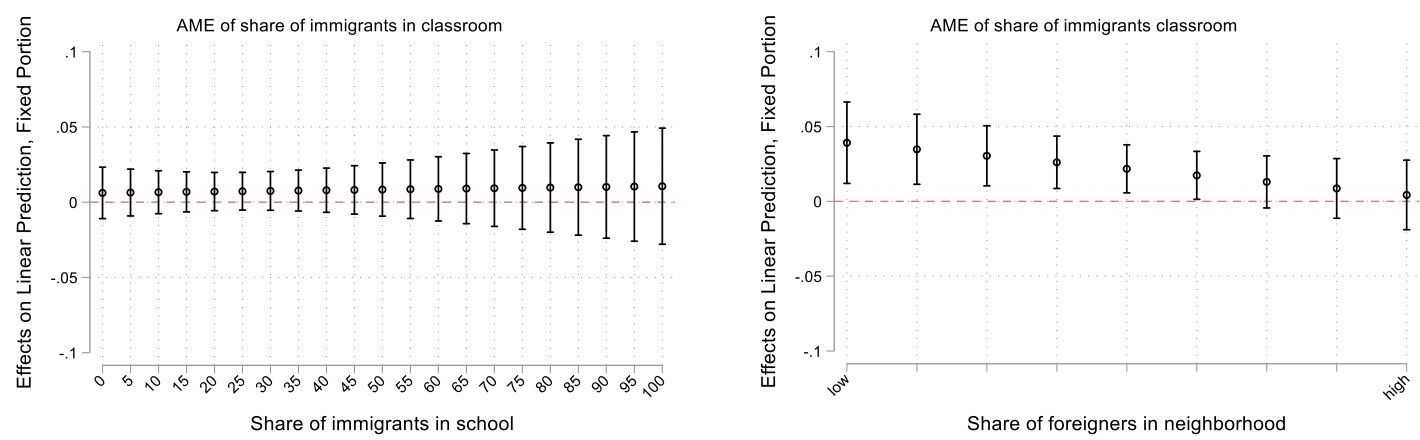

Figure 3. Interactions between social and immigrant/foreigner composition on the level of classrooms, schools and neighborhoods. Left panel: interaction between classroom and school composition; right panel: interaction between classroom and neighborhood composition. Data: NEPS-SC2, microm consumer marketing. 
We do not find any significant interaction between compositional characteristics on the school and the classroom level (figure 3, left panel). This might be due to the relation between school and classroom being rather of substitutable (i.e., mediating) than of multiplicative nature as already indicated by the models in Table 2. However, we do find significant interactions between classroom and neighborhood characteristics. First, there is evidence for a reinforcement between classrooms' and neighborhoods' social composition. The higher the share of both high-SES students in classroom and neighborhood is, the more likely it is for the teacher to have higher expectations towards his/her students (figure 3, upper right panel). This partially supports our second hypothesis. In contrast, we find an unexpected interaction between the composition of foreigners in the neighborhood and the share of immigrant students' in the classroom: The positive association between the classroom-level share of immigrants and teachers' expectations is particularly pronounced when the share of foreigners in the neighborhood is low. This indicates that teachers are only positively framed by a high share of non-native students in the classroom, when the school's neighborhood does not evoke situational cues such as 'foreigner district'. While this result comes as a surprise substantially, it yet supports our general argument that several frames are embedded within one another as a consequence of which (educational) context conditions on different levels may be multiplicatively interrelated (Cook 2003, McVee et al. 2005, p. 537).

In a third step, we integrated the institutional preconditions in our analytical framework. We assumed that educational contexts matter less for teachers' assessments when teachers' perceived relevance of their expectations is high. We test this assumption by including the institutional regulations on the bindingness versus non-bindingness of teachers' recommendation at the end of elementary school, which differ by federal state. We argue that in a binding context, with less leeway for parents to engage in the decision on the secondary school track, teachers will take their decision more serious and should thus be less influenced by contextual conditions such as the social or migration composition of contexts. We test this hypothesis by estimating interactions between the binding versus non-binding recommendation practice and contextual compositions. Results are displayed in Figure 4. As in line with our assumptions, the classroom-level turned out to be most relevant for teachers' expectations (table 2), we focus on the interaction between classroom compositional characteristics and the (non-)bindingness of the recommendation. 

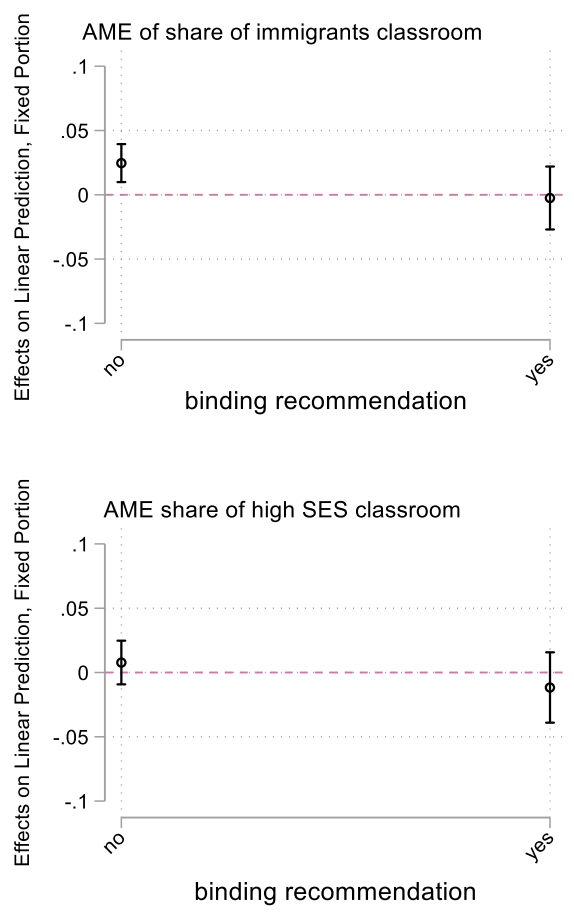

Figure 4. Interaction between binding versus non-binding recommendation practice and immigrant/foreigner and social composition in classroom and neighborhood. Data: NEPS-SC2, microm consumer marketing.

We find a significant association between teachers' recommendations and the share of immigrant students in the classroom only in non-binding contexts. This result is in line with our third hypothesis, where we argued that teachers are less likely to be influenced by contextual conditions when the consequences of their expectations or recommendations are more serious and have a greater impact and relevance. We also find the influence of the share of foreigners in the neighborhood to be significant only if the recommendation practice is non-binding (see Figure A1 in the appendix). These findings confirm the general argument of dual-process theory that automatic processing is more likely when the consequences of a decision are less serious. In situations in which the teacher is the sole decision maker, it is more likely that s/he reflects more carefully and does not take compositional characteristics of educational contexts into account. To underpin our results, we tested our hypothesis with other institutional configurations such as the orientation phase and comprehensive schools (see Figures A2a and b in the appendix). They point in the same direction, supporting our findings. 


\section{Conclusion}

Research has shown that teachers represent a central dimension of social stratification in the school system in several ways, for instance, by exerting short-term effects on students' motivational development and achievement, but also by shaping students' life chances by influencing students' educational transition prospects and even their occupational chances and labor-market income in the longer run. The reason why teachers do matter is that their assessments of their students (i.e., judgments or expectations) are only reasonably accurate when compared to established criteria such as performance and motivation, while a residual component of conditional inaccuracy remains. It is this residual inaccuracy that may take effect on students' educational development and later life chances, which is why research on the exact sources of inaccuracy is of vital importance for the study of both educational inequality and the social stratification of individuals' life courses.

The aim of the present contribution is to analyze the role that multiple and simultaneously observed contexts play in forming teachers' expectations about their students in three consecutive years of elementary school In that sense, we add to the literature on potential sources of inaccuracy in teachers' assessments. The objectives of this paper were hereby: providing an extensive literature review on research discussing the (possible) relevance of contexts for teacher assessments, introducing a theoretical dual-process model (Lizardo et al. 2016, Miles et al. 2019, Vaisey 2009) that allows to formulate hypotheses on the simultaneous influence of contexts, and empirically assessing the separate and combined relevance of several contexts on teachers' expectations of elementary school students in Germany. The contextual levels that we focused on were the classroom, the school, the neighborhood and the level of institutions. Our main argument was that the social and migration composition on different contextual levels constitute salient social categories that can shift (or 'frame away') teachers' assessments from a more rational evaluation to more automatic processing. We connected our dual-process argument to the idea of interrelations of educational contexts. Concretely, we postulated effects of multiple educational context conditions on teachers' assessments to reinforce one another. In addition, we argued that the educational setting determines how much importance teachers associate with their assessments. In tracked education systems such as the German, teachers are obliged to communicate explicit track recommendations for secondary school at the end of elementary school. The extent to which these track recommendations are binding varies across German federal states. We assumed that in binding institutional settings, teachers associate more relevance to their assessments, which will following dual-process theory - lead to a more rational processing and less relevance of context composition influences. 
We tested our hypotheses by employing data from the Starting Cohort 2 of the German National Educational Panel Study (NEPS). The NEPS-SC2 is a rich data set that comprises extensive information on students, teachers, and parents on the one hand, and classroom, school, and neighborhood composition on the other hand. We found some evidence that educational context conditions influence teachers' expectations. However, the only significant and robust association was found for the share of immigrant students in the classroom which positively affect teachers' expectations of their students. This association only holds for German students, indicating a relative advantage for German students if their share in the classroom is small. An alternative interpretation of this finding might be that a high share of migrants in the classroom leads to an underperformance of German students, as a consequence of which the positive association between the share of migrants and teachers' assessments would merely reflect that teachers accurately assess German students' 'true' potential. However, as a robustness check we have included the classroom-average level of performance in our analyses which did not alter the positive association between the share of migrants in the classroom and teachers' assessments. Hence, based on our findings we are confident to argue that a high share of migrants in the classroom constitutes a source of inaccuracy for teachers' assessments (of native students). Thus, the classroom as the most immediate context represents also the most relevant frame of reference for teachers to form their expectations. In contrast to our hypothesis, we did not find any other contextual effect to be significant after including a wide set of student, teacher, and parental control variables. However, in line with our theoretical expectations, our results support the idea of multiplicative framing effects. In particular, we found the social composition of classrooms and neighborhoods to be mutually reinforcing in their relation to teachers' expectations. We could not observe any tendency of mutual attenuation between contexts.

Furthermore, we observed the contextual-level inaccuracy of teacher expectations to be especially relevant when the consequences of the teacher's expectations are less relevant (non-binding recommendation), and thus, less serious for students' educational prospects. The importance of the decisional relevance as a framing mechanism is emphasized by additional analyses in which we interacted educational context characteristics other institutional configurations (see Figures $\mathrm{A} 2 \mathrm{a}$ and $\mathrm{b}$ in the appendix) and the time of assessment (available upon request). In either case, results indicate that the more relevant the decision is for teachers, the less influence educational context characteristics seem to have on their decision.

There are several limitations of the present study. First, while we have used a dual-process approach to deduce hypotheses on the interplay of contextual effects on different analytical levels, limitations in data availability prevented any direct test of some crucial concepts of dual process and framing theory. 
Consequently, future studies should apply recent progress in the measurement of automatic cognition (Miles et al. 2019) to the subject matter of teachers' assessments and their dependence from mutually enforcing educational contexts. Second, due to data limitations, we have only been able to measure variables on the school level but not to model schools as a distinct level of analysis separate from neighborhoods. We have computed robust standard errors to address that same-school students are on average more similar to one another than students from different schools, however, a clear distinction of school and neighborhood level would be preferable for a more satisfactory separation of variance components on each level of analysis. Third, our measure of institutional variation has been restricted to a single educational system, the case of Germany. As an advancement of our research, future studies could consider a wider range of educational systems, each of which structured by distinct patterns of standardization and stratification. These differences in educational policy might 'frame' teachers' perceived consequences of their assessments in different ways.

Cognizant of the aforementioned limitations, our findings allow for a few practical implications which relate the specific concept of empirical accuracy of teachers' assessments to a more general discussion of social inequality of educational systems. First, as a very general recommendation, teachers should be better sensitized that on average, their assessments may depend on criteria on different levels which are not directly related to students' performance, aptitude or motivation. To be sure, our results replicate previous findings in that the practical relevance of potential individual-level stereotypes such as the ones based on students' social or migrant background is considerably higher than potential framing effects of contextual-level stereotypes. Second, our research contributes to the persistent discussion on educational tracking (Furuta 2019). Earlier research has already found that in tracked educational systems, educational inequality may increase if elementary school teachers' track recommendations are not binding for their students: high (vs. low) SES parents could make use of the opportunity to push their children to a higher (vs. lower) track than recommended (Dollmann 2016). Our research adds that social and migration context conditions on the classroom, school, and neighborhood level may be an additional source of inequality in educational opportunity that is particularly present in institutional contexts where track recommendations are nonbinding. Since these influences already begin to take effect several years before students' actual educational transition, they may accumulate over time. As more recent Dutch studies observed that social inequalities might yet increase after a reform from non-binding to binding track recommendations (e.g., Feron 2018), we conclude with the demand for an analysis of the interrelation of educational context conditions also on higher institutional levels than the one analyzed in the paper at hand. 


\section{References}

Agirdag, Orhan, Mieke Van Houtte and Piet Van Avermaet. 2013. "School Segregation and Self-Fulfilling Prophecies as Determinants of Academic Achievement in Flanders." Pp. 46-74 in Early School Leaving \& Amp; Youth Unemployment, edited by S. De Groof and M. Elchardus. Leuven/Amsterdam: Lannoo Campus/Amsterdam University Press.

Ainsworth, James W. 2002. "Why Does It Take a Village? The Mediation of Neighborhood Effects on Educational Achievement." Social Forces 81(1):117-52.

Alexander, Karl and Bruce K. Eckland. 1975. "Contextual Effects in the High School Attainment Process." American Sociological Review 40(3):402-16.

Alwin, Duane F. and Luther B. Otto. 1977. "High School Context Effects on Aspirations." Sociology of Education 50(4):259-73.

Bandura, Albert. 1986. Social Foundations of Thought and Action: A Social Cognitive Theory. Englewood Cliffs, NJ: Prentice-Hall, Inc.

Bates, Littisha A. and Jennifer E. Glick. 2013. "Does It Matter If Teachers and Schools Match the Student? Racial and Ethnic Disparities in Problem Behaviors." Social Science Research 42(5):1180-90.

Baudson, Tanja Gabriele, Antoine Fischbach and Franzis Preckel. 2016. "Teacher Judgments as Measures of Children's Cognitive Ability: A Multilevel Analysis." Learning and Individual Differences 52:148-56.

Becker, Dominik. 2013. "The Impact of Teachers' Expectations on Students' Educational Opportunities in the Life Course: An Empirical Test of a Subjective Expected Utility Explanation." Rationality and Society 25(4):422-69.

Benner, Aprile D. and Sandra Graham. 2013. "The Antecedents and Consequences of Racial/Ethnic Discrimination During Adolescence: Does the Source of Discrimination Matter?". Developmental Psychology 49(8):1602-02.

Bernstein, Basil. 1971. "On the Classification and Framing of Educational Knowledge." Pp. 47-69 in Knowledge and Control: New Directions for the Sociology of Education, edited by M. F. D. Young. London: Collier MacMillan.

Bernstein, Basil. 1981. "Codes, Modalities, and the Process of Cultural Reproduction: A Model." Language in society 10(3):327-63.

Biggs, Michael. 2009. "Self-Fulfilling Prophecies." Pp. 294-314 in The Oxford Handbook of Analytical Sociology, edited by P. Baerman and P. Hedström. Oxford: Oxford University Press.

Blalock, Hubert M. 1956. "Economic Discrimination and Negro Increase." American Sociological Review 21(5):584-88.

Blau, Peter M. 1960. "Structural Effects." American Sociological Review 25(2):178-93.

Blossfeld, Hans-Peter, Hans-Günther Roßbach and Jutta von Maurice, eds. 2011. Education as a Lifelong Process - the German National Educational Panel Study (Neps). Zeitschrift Für Erziehungswissenschaft (Special Issue), Vol (14).

Boone, Simon, Sarah Thys, Piet Van Avermaet and Mieke Van Houtte. 2018. "Class Composition as a Frame of Reference for Teachers? The Influence of Class Context on Teacher Recommendations." British Educational Research Journal 44(2):27493.

Bourdieu, Pierre. 1973. "Cultural Reproduction and Social Production." Pp. 71-112 in Knowledge, Education, and Cultural Change: Papers in the Sociology of Education, edited by R. Brown. London: Tavistock Publications.

Bourdieu, Pierre. 1986. Distinction: A Social Critique of the Judgement of Taste. London: Routledge.

Bowen, Natasha K. and Gary L. Bowen. 1999. "Effects of Crime and Violence in Neighborhoods and Schools on the School Behavior and Performance of Adolescents." Journal of Adolescent Research 14(3):319-42.

Brännström, Lars. 2008. "Making Their Mark: The Effects of Neighbourhood and Upper Secondary School on Educational Achievement." European Sociological Review 24(4):463-78.

Brault, Marie-Christine, Michel Janosz and Isabelle Archambault. 2014. "Effects of School Composition and School Climate on Teacher Expectations of Students: A Multilevel Analysis." Teaching and Teacher Education 44:148-59.

Bronfenbrenner, Urie. 1977. "Toward an Experimental Ecology of Human Development." American Psychologist 32(7):513-22.

Buchmann, Claudia and Hyunjoon Park. 2009. "Stratification and the Formation of Expectations in Highly Differentiated Educational Systems." Research in Social Stratification and Mobility 27(4):245-67.

Canache, Damarys. 1996. "Looking out My Back Door: The Neighborhood Context and Perceptions of Relative Deprivation." Political Research Quarterly 49(3):547-71.

Card, David and Jesse Rothstein. 2007. "Racial Segregation and the Black--White Test Score Gap." Journal of Public Economics 91(1112):2158-84.

Carlson, Deven and Joshua M Cowen. 2015. "Student Neighborhoods, Schools, and Test Score Growth: Evidence from Milwaukee, Wisconsin." Sociology of Education 88(1):38-55.

Catsambis, Sophia and Andrew A. Beveridge. 2001. "Does Neighborhood Matter? Family, Neighborhood, and School Influences on Eighth-Grade Mathematics Achievement." Sociological Focus 34(4):435-57.

Cebolla-Boado, Héctor and Luis Garrido Medina. 2010. "The Impact of Immigrant Concentration in Spanish Schools: School, Class, and Composition Effects." European Sociological Review 27(5):606-23.

Chaiken, Shelly. 1980. "Heuristic Versus Systematic Information Processing and the Use of Source Versus Message Cues in Persuasion." Journal of Personality and Social Psychology 39(5):752-66.

Chetty, Raj, John N. Friedman and Jonah E. Rockoff. 2014. "Measuring the Impacts of Teachers I: Evaluating Bias in Teacher 
Value-Added Estimates." The American Economic Review 104(9):2593-632.

Chetty, Raj, John N. Friedman, Jonah E. Rockoff and Others. 2014. "Measuring the Impacts of Teachers Ii: Teacher Value-Added and Student Outcomes in Adulthood." American Economic Review 104(9):2633-79.

Coburn, Cynthia E. 2004. "Beyond Decoupling: Rethinking the Relationship between the Institutional Environment and the Classroom." Sociology of Education 77(3):211-44.

Cook, Thomas D. 2003. "The Case for Studying Multiple Contexts Simultaneously." Addiction 98:151-55.

Crane, Jonathan. 1991. "The Epidemic Theory of Ghettos and Neighborhood Effects on Dropping out and Teenage Childbearing." American Journal of Sociology 96(5):1226-59.

Davis, James A. 1966. "The Campus as a Frog Pond: An Application of the Theory of Relative Deprivation to Career Decisions of College Men." The American Journal of Sociology 72(1):17-31.

Dietrich, Julia, Anna-Lena Dicke, Bärbel Kracke and Peter Noack. 2015. "Teacher Support and Its Influence on Students' Intrinsic Value and Effort: Dimensional Comparison Effects across Subjects." Learning and Instruction 39:45-54.

Dollmann, Jörg. 2016. "Less Choice, Less Inequality? A Natural Experiment on Social and Ethnic Differences in Educational Decision-Making." European Sociological Review 32(2):203-15.

Driessen, Geert, Peter Sleegers and Frederik Smit. 2008. "The Transition from Primary to Secondary Education: Meritocracy and Ethnicity." European Sociological Review 24(4):527-42.

Dunkake, Imke and Claudia Schuchart. 2015. "Stereotypes and Teacher Characteristics as an Explanation for the Class-Specific Disciplinary Practices of Pre-Service Teachers." Teaching and Teacher Education 50:56-69.

Dunne, Mairead and Louise Gazeley. 2008. "Teachers, Social Class and Underachievement." British Journal of Sociology of Education 29(5):451-63.

Ellen, Ingrid Gould. 2000. "Race-Based Neighbourhood Projection: A Proposed Framework for Understanding New Data on Racial Integration." Urban Studies 37(9):1513-33.

Evans, Jonathan St B. T. 2008. "Dual-Processing Accounts of Reasoning, Judgment, and Social Cognition." Annu. Rev. Psychol. 59:255-78.

Farkas, George. 2003. "Racial Disparities and Discrimination in Education: What Do We Know, How Do We Know It, and What Do We Need to Know?". The Teachers College Record 105(6):1119-46.

Fazio, Russell H. 1990. "Multiple Processes by Which Attitudes Guide Behavior: The Mode Model as an Integrative Framework." Advances in experimental social psychology 23:75-109.

Fekjær, Silje Noack and Gunn Elisabeth Birkelund. 2007. "Does the Ethnic Composition of Upper Secondary Schools Influence Educational Achievement and Attainment? A Multilevel Analysis of the Norwegian Case." European Sociological Review 23(3):309-23.

Feron, Eva, Trudie Schils and Bas Ter Weel. 2016. "Does the Teacher Beat the Test? The Value of the Teacher's Assessment in Predicting Student Ability." De Economist 164(4):391-418.

Feron, Eva. 2018. The Role of Cognitive Tests and Teachers in the Transition from Primary to Secondary

Education. Maastricht: Datawyse / Universitaire Pers Maastricht.

Fiske, Susan T. 1993. "Social Cognition and Social Perception." Annual Review of Psychology 44(1):155-94.

Flouri, Eirini, Dimitrios Tsivrikos, Reece Akhtar and Emily Midouhas. 2015. "Neighbourhood, School and Family Determinants of Children's Aspirations in Primary School." Journal of Vocational Behavior 87:71-79.

Freitag, Markus and Raphaela Schlicht. 2009. "Educational Federalism in Germany: Foundations of Social Inequality in Education." Governance 22(1):47-72.

Furuta, Jared. 2019. "Liberal Individualism and the Globalization of Education as a Human Right: The Worldwide Decline of Early Tracking, 1960-2010." Sociology of Education.

Galster, George C., Anna Santiago, Lisa Stack and Jackie Cutsinger. 2016. "Neighborhood Effects on Secondary School Performance of Latino and African American Youth: Evidence from a Natural Experiment in Denver." Journal of Urban Economics 93:30-48.

Garner, Catherine L. and Stephen W. Raudenbush. 1991. "Neighborhood Effects on Educational Attainment: A Multilevel Analysis." Sociology of Education 64(4):251-62.

Glock, Sabine and Sabine Krolak-Schwerdt. 2013. "Does Nationality Matter? The Impact of Stereotypical Expectations on Student Teachers' Judgments." Social Psychology of Education 16(1):111-27.

Glock, Sabine, Carrie Kovacs and Ineke Pit-ten Cate. 2018. "Teachers' Attitudes Towards Ethnic Minority Students: Effects of Schools' Cultural Diversity." British Journal of Educational Psychology.

Goffman, Erving. 1974. Frame Analysis: An Essay on the Organization of Experience. London: Harper and Row.

Gonos, George. 1977. "'Situation" Versus "Frame": The "Interactionist" and the "Structuralist" Analyses of Everyday Life." American Sociological Review 42(6):854-67.

Goza, Franklin and Igor Ryabov. 2009. "Adolescents' Educational Outcomes: Racial and Ethnic Variations in Peer Network Importance." Journal of Youth and Adolescence 38(9):1264-79.

Gröhlich, Carola and Karin Guill. 2009. "How Stable Are Reference Group Effects of Secondary School Track 
Recommendations?". Journal for Educational Research Online/Journal für Bildungsforschung Online 1(1):154-71.

Hallinan, Maureen T. 1994. "Tracking: From Theory to Practice." Sociology of Education 67(2):79-84.

Hao, Lingxin and Melissa Bonstead-Bruns. 1998. "Parent-Child Differences in Educational Expectations and the Academic Achievement of Immigrant and Native Students." Sociology of Education 71(3):175-98.

Harding, David J. 2011. "Rethinking the Cultural Context of Schooling Decisions in Disadvantaged Neighborhoods: From Deviant Subculture to Cultural Heterogeneity." Sociology of Education 84(4):322-39.

Hechter, Michael and Satoshi \%J Annual review of sociology Kanazawa. 1997. "Sociological Rational Choice Theory." Annual Review of Sociology 23(1):191-214.

Hermansen, Are Skeie and Gunn Elisabeth Birkelund. 2015. "The Impact of Immigrant Classmates on Educational Outcomes." Social Forces 94(2):615-46.

Hinnant, J. Benjamin, Marion O'Brien and Sharon R. Ghazarian. 2009. "The Longitudinal Relations of Teacher Expectations to Achievement in the Early School Years." Journal of Educational Psychology 101(3):662-70.

Horrace, William C. and Ronald L. Oaxaca. 2006. "Results on the Bias and Inconsistency of Ordinary Least Squares for the Linear Probability Model." Economics Letters 90(3):321-27.

Hox, Joop J. 2010. Multilevel Analysis - Techniques and Applications. New York and Hove: Routledge.

Hunt, Matthew O., Lauren A. Wise, Marie-Claude Jipguep, Yvette C. Cozier and Lynn Rosenberg. 2007. "Neighborhood Racial Composition and Perceptions of Racial Discrimination: Evidence from the Black Women's Health Study." Social Psychology Quarterly 70(3):272-89.

Jencks, Christopher and Susan E. Mayer. 1990. "The Social Consequences of Growing up in a Poor Neighborhood." Pp. 111-86 in Inner-City Poverty in the United States, edited by L. E. Lynn and F. H. McGeary. Washington, DC: National Academy Press.

Jussim, Lee. 1986. "Self-Fulfilling Prophecies: A Theoretical and Integrative Review." Psychological Review 93(4):429-45.

Jussim, Lee, Jacquelynne Eccles and Stephanie Madon. 1996. "Social Perception, Social Stereotypes, and Teacher Expectations: Accuracy and the Quest for the Powerful Self-Fulfilling Prophecy." Pp. 281-388 in Advances in Experimental Social Psychology, Vol. 28, edited by M. P. Zanna. San Diego: Academic Press.

Jussim, Lee and Kent D. Harber. 2005. "Teacher Expectations and Self-Fulfilling Prophecies: Knowns and Unknowns, Resolved and Unresolved Controversies." Personality and Social Psychology Review 9(2):131-55.

Kaiser, Johanna, Anna Südkamp and Jens Möller. 2017. "The Effects of Student Characteristics on Teachers' Judgment Accuracy: Disentangling Ethnicity, Minority Status, and Achievement." Journal of Educational Psychology 109(6):871-71.

Kauppinen, Timo M. 2008. "Schools as Mediators of Neighbourhood Effects on Choice between Vocational and Academic Tracks of Secondary Education in Helsinki." European Sociological Review 24(3):379-91.

Krolak-Schwerdt, Sabine, Matthias Böhmer and Cornelia Gräsel. 2013. "The Impact of Accountability on Teachers' Assessments of Student Performance: A Social Cognitive Analysis." Social Psychology of Education 16(2):215-39.

Kroneberg, Clemens and Frank Kalter. 2012. "Rational Choice Theory and Empirical Research: Methodological and Theoretical Contributions in Europe." Annual Review of Sociology 38:73-92.

Lamont, Michèle. 2012. "Toward a Comparative Sociology of Valuation and Evaluation." Annual Review of Sociology 38:201-21.

Liem, Gregory Arief D, Herbert W Marsh, Andrew J Martin, Dennis M McInerney and Alexander S Yeung. 2013. "The Big-FishLittle-Pond Effect and a National Policy of within-School Ability Streaming: Alternative Frames of Reference." American Educational Research Journal 50(2):326-70.

Lizardo, Omar, Robert Mowry, Brandon Sepulvado, Dustin S. Stoltz, Marshall A. Taylor, Justin Van Ness and Michael Wood. 2016. "What Are Dual Process Models? Implications for Cultural Analysis in Sociology." Sociological Theory 34(4):287-310.

Madon, Stephanie, Lee Jussim and Jacquelynne Eccles. 1997. "In Search of the Powerful Self-Fulfilling Prophecy." Journal of Personality and Social Psychology 72(4):791-809.

Marsh, Herbert W, Hans Kuyper, Alexandre JS Morin, Philip D Parker and Marjorie Seaton. 2014. "Big-Fish-Little-Pond Social Comparison and Local Dominance Effects: Integrating New Statistical Models, Methodology, Design, Theory and Substantive Implications." Learning and Instruction 33:50-66.

Marsh, Herbert W. 1987. "The Big-Fish-Little-Pond Effect on Academic Self-Concept." Journal of Educational Psychology 79(3):28095.

Mayer, Susan E. and Christopher Jencks. 1989. "Growing up in Poor Neighborhoods: How Much Does It Matter?". Science 243(4897):1441-45.

McGrady, Patrick B. and John R. Reynolds. 2013. "Racial Mismatch in the Classroom: Beyond Black-White Differences." Sociology of Education 86(1):3-17.

McKown, Clark and Rhona S. Weinstein. 2008. "Teacher Expectations, Classroom Context, and the Achievement Gap." Journal of School Psychology 46(3):235-61.

McVee, Mary B., Kailonnie Dunsmore and James R. Gavelek. 2005. "Schema Theory Revisited." Review of Educational Research 75(4):531-66.

Meissel, Kane, Frauke Meyer, Esther S. Yao and Christine M. Rubie-Davies. 2017. "Subjectivity of Teacher Judgments: Exploring 
Student Characteristics That Influence Teacher Judgments of Student Ability." Teaching and Teacher Education 65:48-60.

Miles, Andrew, Raphaël Charron-Chénier and Cyrus Schleifer. 2019. "Measuring Automatic Cognition: Advancing Dual-Process Research in Sociology." American Sociological Review 84(2):308-33.

Morris, Edward W. 2005. "From "Middle Class" to "Trailer Trash:" Teachers' Perceptions of White Students in a Predominately Minority School." Sociology of Education 78(2):99-121.

Muller, Chandra, Catherine Riegle-Crumb, Kathryn S. Schiller, Lindsey Wilkinson and Kenneth A. Frank. 2010. "Race and Academic Achievement in Racially Diverse High Schools: Opportunity and Stratification." Teachers College Record 112(4):1038-63.

Newmann, Fred M., Robert A. Rutter and Marshall S. Smith. 1989. "Organizational Factors That Affect School Sense of Efficacy, Community, and Expectations." Sociology of Education 62(4):221-38.

Östh, John, Eva Andersson and Bo Malmberg. 2013. "School Choice and Increasing Performance Difference: A Counterfactual Approach." Urban Studies 50(2):407-25.

Owens, Ann. 2010. "Neighborhoods and Schools as Competing and Reinforcing Contexts for Educational Attainment." Sociology of Education 83(4):287-311.

Pager, Devah and Hana Shepherd. 2008. "The Sociology of Discrimination: Racial Discrimination in Employment, Housing, Credit, and Consumer Markets." Annual Review of Sociology 34:181-209.

Park, Robert E., Ernest Watson Burgess and Roderick Duncan McKenzie. 1925. The City Chicago. Chicago: University Press.

Pit-ten Cate, Ineke M., Sabine Krolak-Schwerdt and Sabine Glock. 2016. "Accuracy of Teachers' Tracking Decisions: Short-and Long-Term Effects of Accountability." European Journal of Psychology of Education 31(2):225-43.

Portes, Alejandro and Lingxin Hao. 2004. "The Schooling of Children of Immigrants: Contextual Effects on the Educational Attainment of the Second Generation." Proceedings of the National Academy of Sciences 101(33):11920-27.

Ready, Douglas D. and David L. Wright. 2011. "Accuracy and Inaccuracy in Teachers' Perceptions of Young Children's Cognitive Abilities." American Educational Research Journal 48(2):335-60.

Rist, Ray C. 1970. "Student Social Class and Teacher Expectations: The Self-Fulfilling Prophecy in Ghetto Education." Harvard Educational Review 40(3):411-51.

Rosenthal, Robert and Lenore Jacobson. 1968. Pygmalion in the Classroom: Teacher Expectation and Pupils' Intellectual Development. New York: Holt, Rinehart \&amp; Winston.

Rumelhart, David E. and Andrew Ortony. 1977. "The Representation of Knowledge in Memory." Pp. 99-135 in Schooling and the Acquisition of Knowledge, edited by R. C. Anderson, R. Spiro and W. E. Montague. Hillsdale, NJ: Lawrence Erlbaum Associates.

Ryabov, Igor. 2011. "Adolescent Academic Outcomes in School Context: Network Effects Reexamined." Journal of Adolescence 34(5):915-27.

Sampson, Robert J., Jeffrey D. Morenoff and Thomas Gannon-Rowley. 2002. "Assessing" Neighborhood Effects": Social Processes and New Directions in Research." Annual Review of Sociology 28:443-78.

Schönberger, Katrin and Tobias Koberg. 2016. Regionaldaten: Microm. Bamberg: Leibniz-Institut für Bildungsverläufe e.V. (LIfBi).

Schulze, Alexander, Felix Wolter and Rainer Unger. 2009. "Bildungschancen Von Grundschülern: Die Bedeutung Des KlassenUnd Schulkontextes Am Übergang Auf Die Sekundarstufe I." Kölner Zeitschrift für Soziologie und Sozialpsychologie 61(3):41135.

Seaton, Eleanor K. and Tiffany Yip. 2009. "School and Neighborhood Contexts, Perceptions of Racial Discrimination, and Psychological Well-Being among African American Adolescents." Journal of Youth and Adolescence 38(2):153-63.

Sewell, William H. and J. Michael Armer. 1966. "Neighborhood Context and College Plans." American Sociological Review 31(2):15968.

Singer, Judith D and John B Willett. 2003. Applied Longitudinal Data Analysis - Modeling Change and Event Occurence. New York: Oxford University Press.

Sorhagen, Nicole S. 2013. "Early Teacher Expectations Disproportionately Affect Poor Children's High School Performance." Journal of Educational Psychology 105(2):465-77.

Südkamp, Anna, Johanna Kaiser and Jens Möller. 2012. "Accuracy of Teachers' Judgments of Students' Academic Achievement: A Meta-Analysis." Journal of Educational Psychology 104(3):743-62.

Szulkin, Ryszard and Jan O. Jonsson. 2007. "Ethnic Segregation and Educational Outcomes in Swedish Comprehensive Schools." SULCIS Working Paper Series (2).

Tach, Laura Marie and George Farkas. 2006. "Learning-Related Behaviors, Cognitive Skills, and Ability Grouping When Schooling Begins." Social Science Research 35(4):1048-79.

Tajfel, Henri. 1982. "Social Psychology of Intergroup Relations." Annual Review of Psychology 33(1):1-39.

Tenenbaum, Harriet R. and Martin D. Ruck. 2007. "Are Teachers' Expectations Different for Racial Minority Than for European American Students? A Meta-Analysis." Journal of Educational Psychology 99(2):253-73.

Tevis, Tenisha L. 2007. African-American Students' College Transition Trajectory: An Examination of the Effects of High School Composition and Expectations on Degree Attainment. Pennsylvania State University: The Graduate School College of Education (PhD 
Thesis).

Thomas, William Isaac and Dorothy Swaine Thomas. 1928. The Child in America: Behavior Problems and Programs. New York: Knopf. Timmermans, Anneke C., Hans Kuyper and Greetje van der Werf. 2015. "Accurate, Inaccurate, or Biased Teacher Expectations: Do D Utch Teachers Differ in Their Expectations at the End of Primary Education?". British Journal of Educational Psychology 85(4):459-78.

Vaisey, Stephen. 2009. "Motivation and Justification: A Dual- Process Model of Culture in Action." American Journal of Sociology 114(6):1675-715.

Van de Werfhorst, Herman G. and Jonathan J. B. Mijs. 2010. "Achievement Inequality and the Institutional Structure of Educational Systems: A Comparative Perspective." Annual Review of Sociology 36:407-28.

van de Werfhorst, Herman G. 2014. "Changing Societies and Four Tasks of Schooling: Challenges for Strongly Differentiated Educational Systems." International Review of Education 60(1):123-44.

Vervaet, Roselien, Fanny D'Hondt, Mieke Van Houtte and Peter A. J. Stevens. 2016. "The Ethnic Prejudice of Flemish Teachers: The Role of Ethnic School Composition and of Teachability." Cultural Diversity and Ethnic Minority Psychology 22(4):55262.

Vliegenthart, Rens and Liesbet Van Zoonen. 2011. "Power to the Frame: Bringing Sociology Back to Frame Analysis." European journal of communication 26(2):101-15.

von Below, Susanne, Justin J. W. Powell and Lance W. Roberts. 2013. "Educational Systems and Rising Inequality: Eastern Germany after Unification." Sociology of Education 86(4):362-75.

Wacquant, Loïc J. D. 1996. "The Rise of Advanced Marginality: Notes on Its Nature and Implications." Acta Sociologica 39(2):12139.

Weßling, Katarina, Andreas Hartung and Steffen Hillmert. 2015. "Spatial Structure Counts: The Relevance of Regional LabourMarket Conditions for Educational Transitions to Vocational Training." Empirical Research in Vocational Education and Training 7(12):1-20.

Wilson, William Julius. 1987. The Truly Disadvantaged: The Inner City, the Underclass, and Public Policy. Chicago: University of Chicago Press.

Zajonc, Robert B. 1968. "Attitudinal Effects of Mere Exposure." Journal of Personality and Social Psychology 9(2 (Part2)):1-27. 


\section{Appendix}

Table A1. Correlation between context level variables. Data: NEPS-SC2, microm consumer marketing

$\begin{array}{llllll}\text { MIG } & \text { HIGH SES } & \text { FOREIGN } & \text { STATUS } & \text { MIG } & \text { HIGH SES } \\ \text { SCHOOL } & \text { SCHOOL } & \text { NEIGHB. } & \text { NEIGHB. } & \text { CLASS } & \text { CLASS }\end{array}$

MIG

SCHOOL $\quad 1.0$

HIGH SES $\quad-0.269 \quad 1.0$

SCHOOL

$0.394 \quad-0.069 \quad 1.0$

NEIGHB.

STATUS

NEIGHB.

$-0.415$

0.305

$-0.123$

1.0

MIG CLASS

0.674

$-0.107$

0.488

$-0.330$

1.0

HIGH SES

CLASS

$-0.205$

0.614

$-0.044$

0.248

$-0.155$

1.0

AME share of foreigners in neighborhood

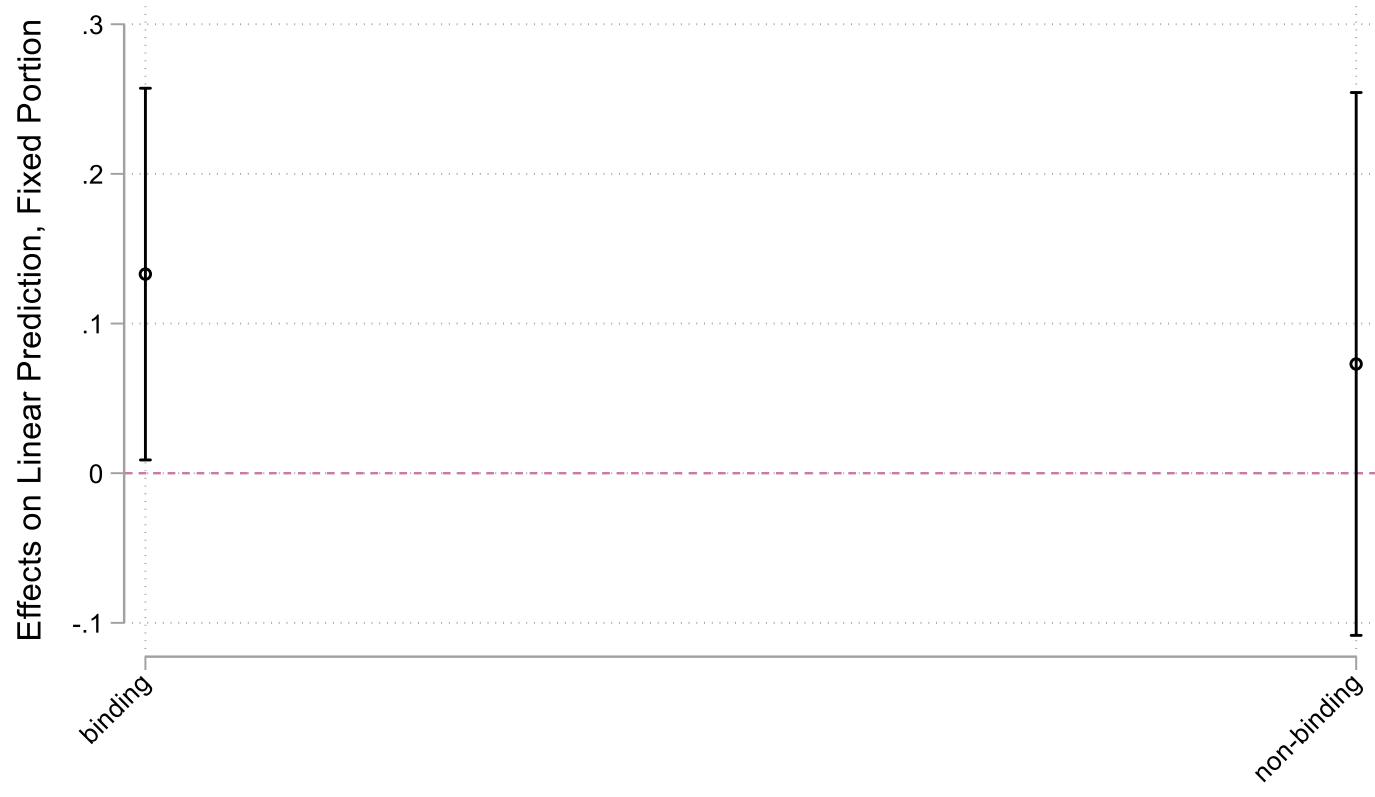

binding vs. non-binding

Figure A1. Interaction between binding and non-binding recommendation and share foreigners in the neighborhood. Data: NEPS-SC2, microm consumer marketing. 

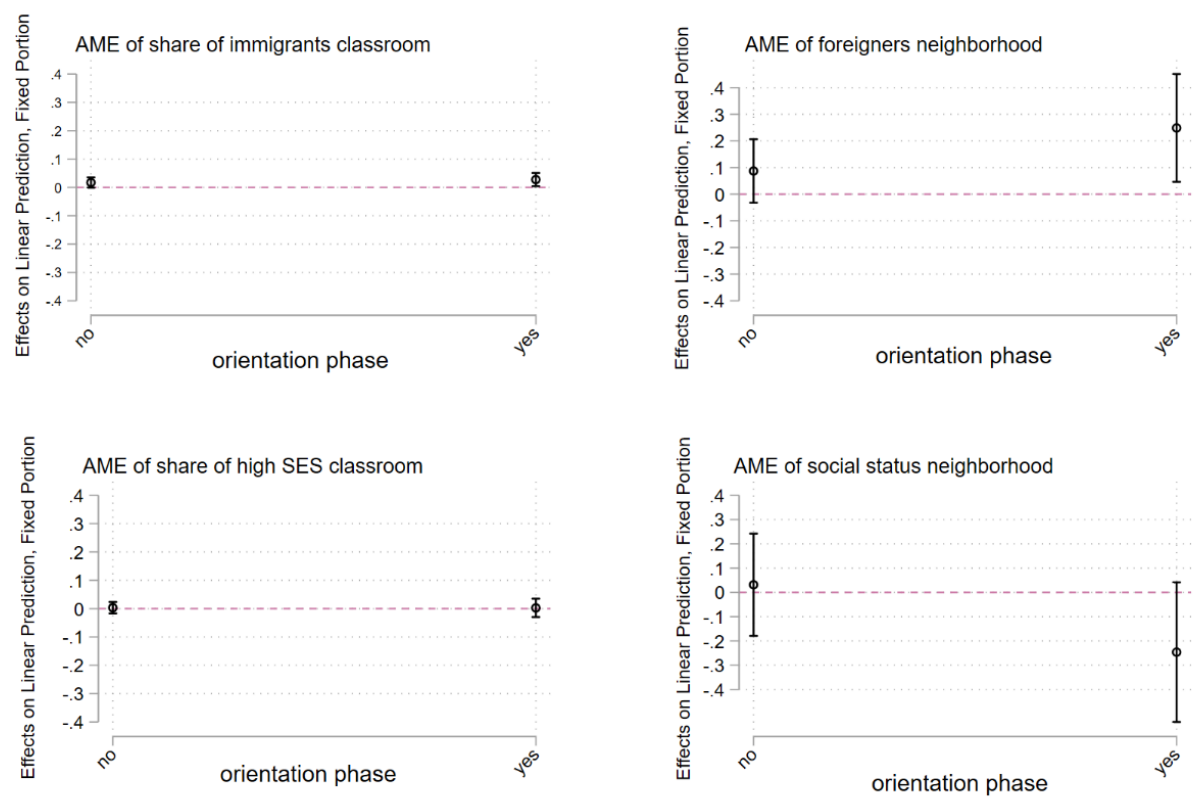

Figure A2a. Interaction between orientation phase versus no orientation phase and social and ethnic composition in the classroom and neighborhood. Data: NEPS-SC2, microm consumer marketing.
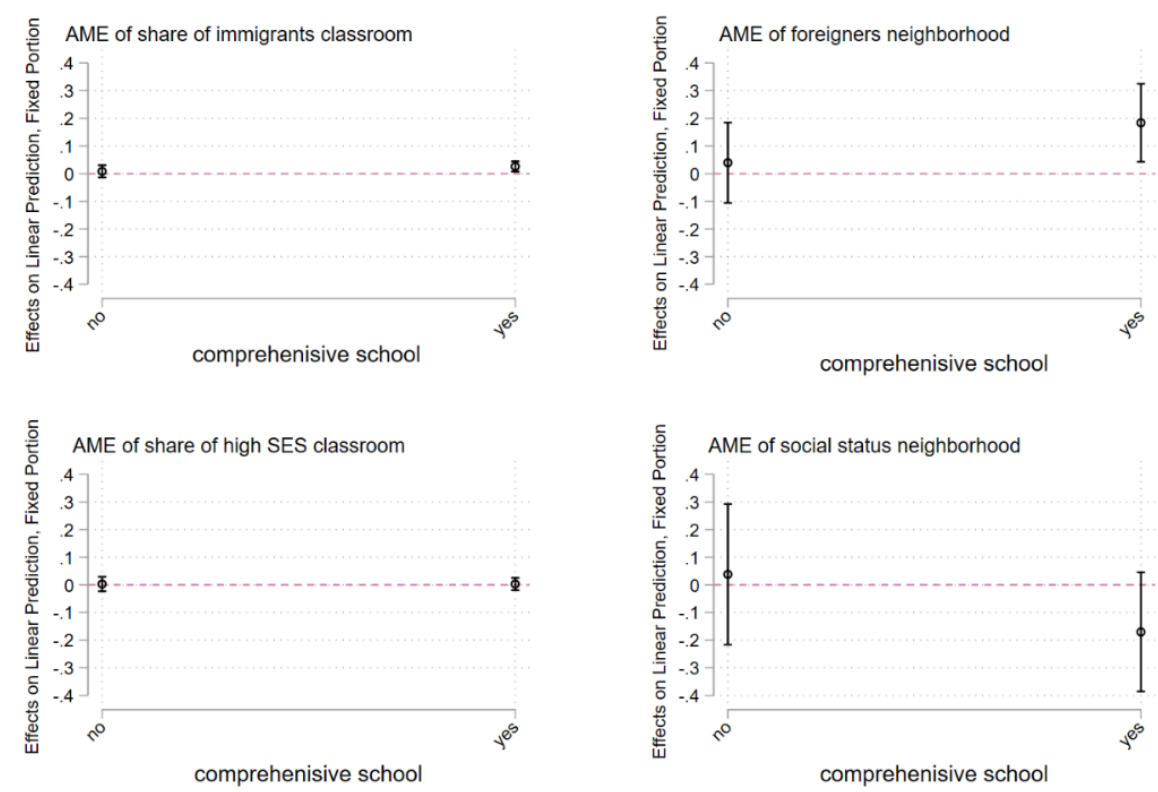

Figure A2b. Interaction between comprehensive schools versus no comprehensive schools and social and ethnic composition in the classroom and neighborhood. Data: NEPS-SC2, microm consumer marketing. 